\title{
Life Cycle Cost Optimization of a Bolig+ Zero Energy Building
}





\section{Life Cycle Cost Optimization of a Bolig+ Zero Energy Building}

PhD Thesis by

Anna Joanna Marszal-Pomianowska

Department of Civil Engineering, The Faculty of Engineering and Science, Aalborg University, Aalborg, Denmark

River Publishers

Aalborg 
ISBN 978-87-92982-26-1 (e-book)

Published, sold and distributed by:

River Publishers

P.O. Box 1657

Algade 42

9000 Aalborg

Denmark

Tel.: +45369953197

www.riverpublishers.com

Copyright for this work belongs to the author, River Publishers have the sole right to distribute this work commercially.

All rights reserved (c) 2012 Anna Joanna Marszal-Pomianowska.

No part of this work may be reproduced, stored in a retrieval system, or transmitted in any form or by any means, electronic, mechanical, photocopying, microfilming, recording or otherwise, without prior written permission from the Publisher. 


\section{Abstract}

Buildings consume approximately $40 \%$ of the world's primary energy use. Considering the total energy consumption throughout the whole life cycle of a building, the energy performance and supply is an important issue in the context of climate change, scarcity of energy resources and reduction of global energy consumption. An energy consuming as well as producing building, labelled as the Zero Energy Building (ZEB) concept, is seen as one of the solutions that could change the picture of energy consumption in the building sector, and thus contribute to the reduction of the global energy use. However, before being fully implemented in the national building codes and international standards, the ZEB concept requires a clear understanding and a uniform definition.

The ZEB concept is an energy-conservation solution, whose successful adaptation in real life depends significantly on private building owners' approach to it. For this particular target group, the cost is often an obstacle when investing money in environmental or climate friendly products. Therefore, this $\mathrm{PhD}$ project took the perspective of a future private ZEB owner to investigate the cost-optimal Net ZEB definition applicable in the Danish context.

The review of the various ZEB approaches indicated a general concept of a Zero Energy Building as a building with significantly reduced energy demand that is balanced by an equivalent energy generation from renewable sources. And, with this as a general framework, each ZEB definition should further specify: (1) the connection or the lack of it to the energy infrastructure, (2) the unit of the balance, (3) the period of the balance, (4) the types of energy use included in the balance, (5) the minimum energy performance requirements (6) the renewable energy supply options, and if applicable (7) the requirements of the building-grid interaction. Moreover, the study revealed that the future ZEB definitions applied in the Denmark should mostly be focused on grid-connected ZEBs - Net ZEBs, and the annual primary energy balance.

The Life Cycle Cost (LCC) analysis conducted with a study case of a multi-storey residential Net ZEB aimed to determine the cost-optimal "zero" energy balance, minimum energy performance requirements and options of supplying renewable energy. The calculation encompassed three levels of energy frames, which mirrored the Danish low-energy building classes included in the current building code, and ten renewable energy supply systems including both on-site and off-site options. The results indicated that although the off-site options have lower life cycle costs than the on-site alternatives, their application would promote renewable technologies over energy efficiency measures. Thus, they oppose the Danish plans to gradually make the energy performance requirements stricter. Moreover, the results showed that district heating is a less cost-attractive solution than a ground source heat pump for a private building owner. Finally, with 2010-level of energy prices, cost-optimal "zero" energy balance accounts only for the building related energy use. 


\section{Dansk resumé}

Bygninger er ansvarlige for omkring $40 \%$ af verdens primære energiforbrug. Hvis man tager det totale forbrug igennem en bygnings komplette livscyklus i betragtning, er energiforbrug og -produktion et vigtigt emne, når det sættes i konteksten af klimaændringer, mangel på energikilder og reduktionen af det globale energiforbrug. En energiforbrugende såvel som energiproducerende bygning kaldet Zero Energy Building (ZEB) - energineutralt byggeri - anses for en af de løsninger, der kan være med til at ændre energiforbrugsbilledet i byggesektoren og derved bidrage til reduktion af det globale energiforbrug. Dog kræver ZEB-konceptet en klar forståelse og ensartet definition før det kan implementeres fuldt ud i nationale byggevedtægter og internationale standarder.

ZEB-konceptet er en energibesparende løsning hvis succesfulde tilpasning til det virkelige liv i særdeleshed afhænger af den private bygningsejers tilgang til dette. For denne målgruppe er omkostningerne ofte en barriere når der skal investeres penge $\mathrm{i}$ miljø- og klimavenlige produkter. Derfor har dette ph.d.-projekt taget udgangspunkt i en fremtidig privat ZEB ejer, for at undersøge den omkostningsoptimale ZEB definition, der kan anvendes i en dansk kontekst.

Undersøgelsen af forskellige ZEB-tilgange indikerede et gennemgående koncept for energineutralt byggeri - Zero Energy Building - som en bygning med betydeligt reduceret energibehov, der er afbalanceret med en tilsvarende energiproduktion fra vedvarende energikilder. Og med dette som en general ramme bør hver ZEB-definition præciseres yderligere med hensyn til: (1) forbindelse til energiinfrastrukturen eller mangel på samme, (2) enhed benyttet til beregning af balancen, (3) balanceperioden, (4) energibrugstyper i balancen, (5) krav til minimum energiydeevne, (6) muligheder for vedvarende energiforsyning, og (7) krav til interaktionen mellem energiforsyningen og bygningen. Desuden har undersøgelsen afsløret, at de fremtidige ZEB-definitioner, der skal anvendes i Danmark, bør være mest fokuseret på ZEB'er, der er forbundet med energiforsyningen - net ZEB'er og den årlige primære energi balance.

En Life Cycle Cost (LCC) - livscyklusomkostninger - analyse blev udført i form af en undersøgelse af en etagebolig net ZEB med det formål at fastslå henholdsvis den omkostningsoptimale "nul" energibalance, kravene til minimum energiydeevne og mulighederne for at forsyne bygningen med vedvarende energi. Beregningerne omfattede tre niveauer af energirammer, der afspejlede de danske lavenergibygningsklassifikationer inkluderet $\mathrm{i}$ nuværende byggevedtægter og ti vedvarende energiforsyningssystemer med både on-site og off-site forsynings muligheder. Resultaterne viste, at selv om off-site mulighederne har lavere livscyklusomkostninger i forhold til on-site alternativerne kan brugen af dem fremme vedvarende energiteknologier frem for energieffektive og - besparende teknologier. Således modarbejder det de danske planer om gradvis at gøre kravene strammere for energibehovet. Ydermere viste resultaterne, at fjernvarme er en mindre omkostningsfordelagtig løsning end en varmepumpe for en privat bygningsejer. Endeligt regner den omkostningsoptimale "nul"-energibalance kun for det bygningsrelaterede energiforbrug med 2010-niveau energipriser. 


\section{Contents}

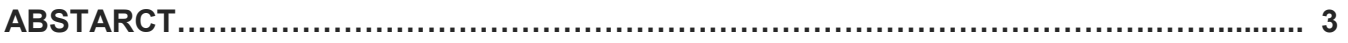

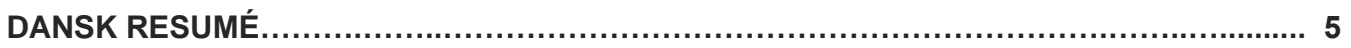

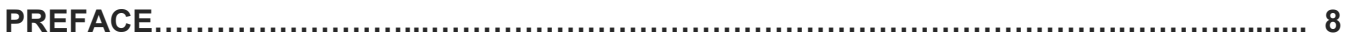

$1 \quad$ INTRODUCTION.................................................................................. 10

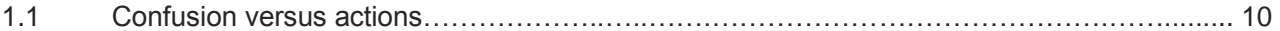

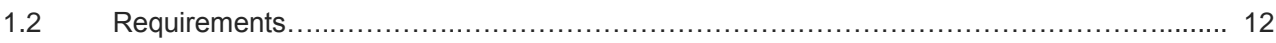



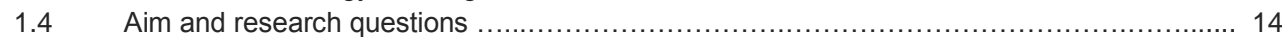

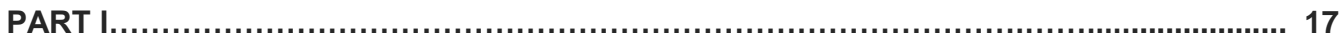

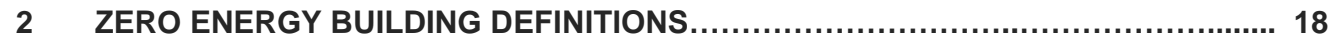

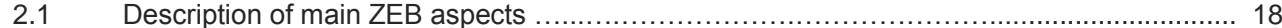

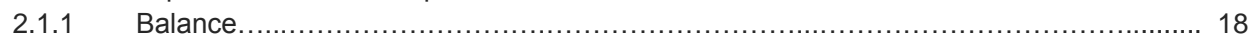

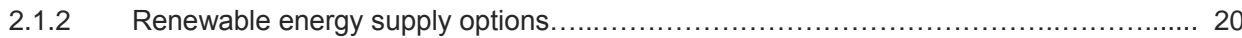

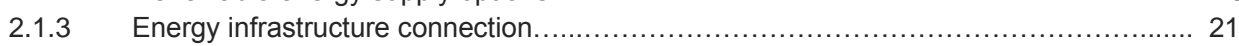

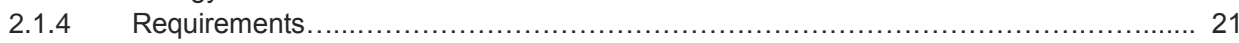

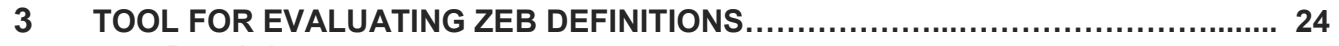

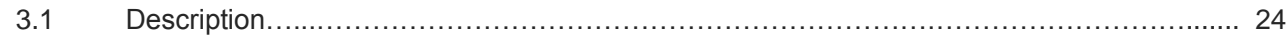

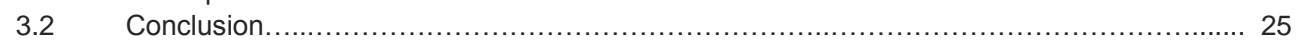

4 NATIONAL ROADMAPS TOWARDS ZEB AND "KNOWN ZEB CALCULATION

PRACTICES" .................................................................................. 26



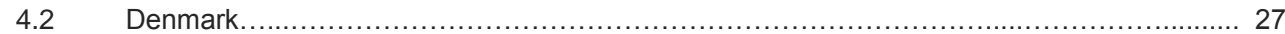

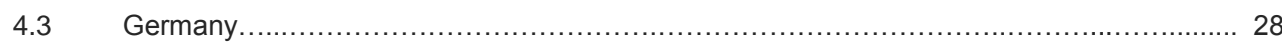

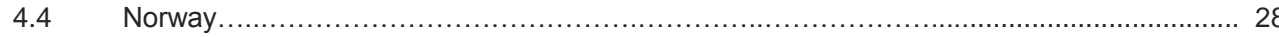

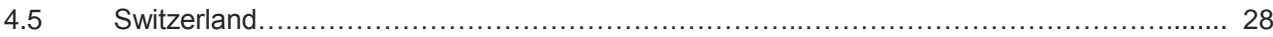



$5 \quad$ CONCLUDING REMARS PART I......................................................... 31

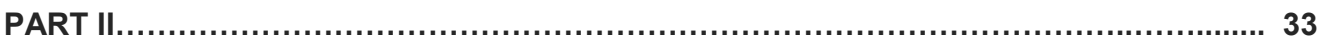

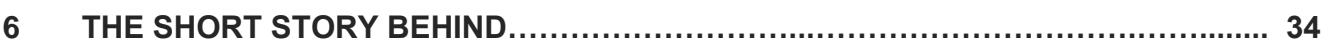

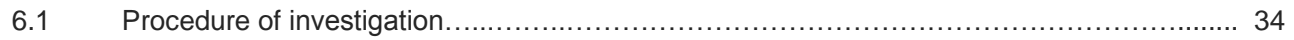

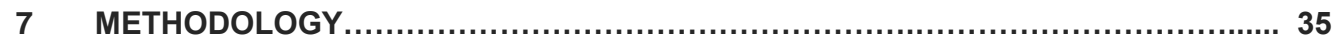

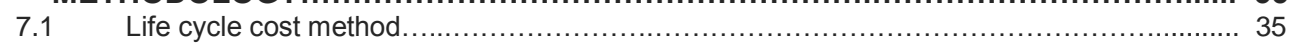

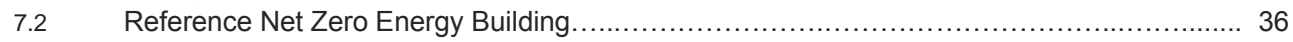

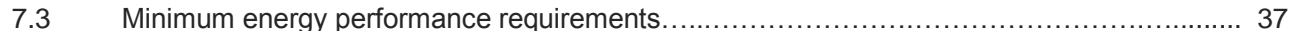

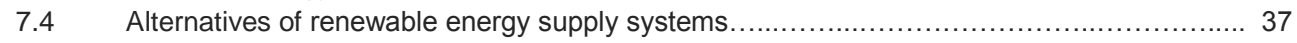

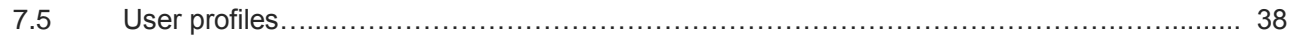

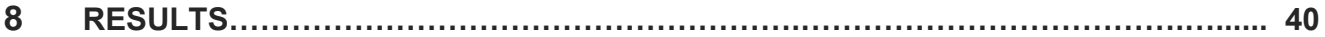

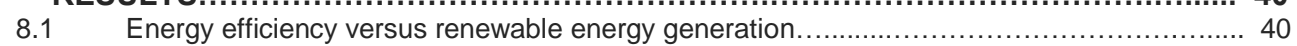

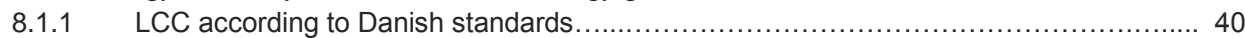

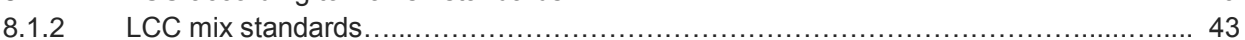

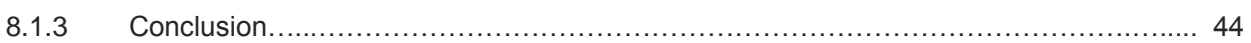

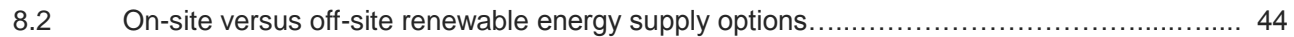


8.2.1 LCC mix standards...................... 44

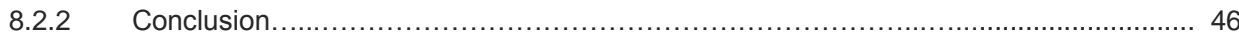

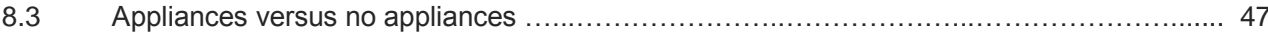

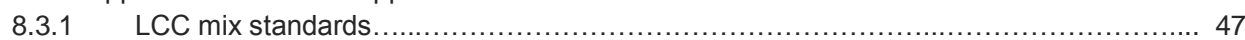

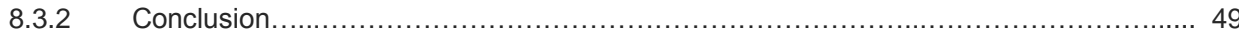



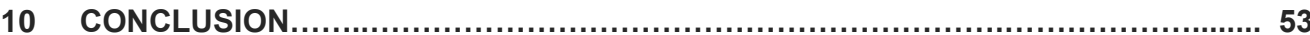



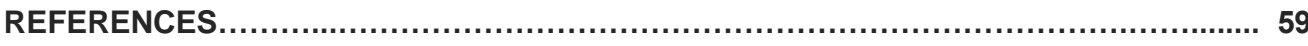

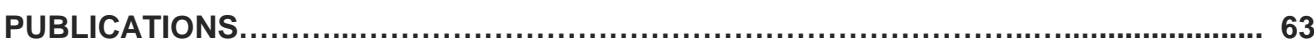




\section{Preface}

This thesis represents a part of the fulfillment for acquiring the Ph.D. degree. The thesis will be presented at Aalborg University on February 7th, 2011.

This PhD project is part of the Strategic Research Centre on Zero Energy Buildings and it was financed by Energiteknologisk Udviklings- og Demonstrationsprogram (EUDP). The work has been supervised by Professor Per Heiselberg and Professor Henrik Lund.

I would like to thank Per Heiselberg for his continuous guidance, inspiring and fruitful discussions and his support and faith in me. Also, Henrik Lund I want to thank for his guidance and constructive comments. Additionally, I would like to express my thanks to all my colleagues from the Indoor Environmental Engineering Research Group, Strategic Research Centre on ZEBs, and others at the Department of Civil Engineering.

I would also like to thank all participants of the joint IEA SHC Task40 / ECBCS Annex52 "Towards Net Zero Energy Solar Buildings" for inspiring conversations, fruitful collaboration and letting me realise that all of us struggle with finding answers for our inquiries. Special thanks to Kim B. Wittchen and Søren Ø. Jensen for their great help, support and fantastic travel companionship.

Finally, I would like to thank my family and friends for believing in me and for supporting me thorough the rough patches that turn up on the road once in a while.

\section{Anna Marszal}

December 2011 
Looking at the main framework of Zero Energy Buildings, namely that the total building energy consumption should come from renewable energy sources, let me realize that ZEB is not a completely new building concept, but rather a modern name for buildings heated with wood or straw and lighted with candles. And, we have actually came back full circle, but this time we can use more sophisticated technologies to meet our goal of "zero".

Anna Marszal 


\section{Introduction}

After the oil crisis in the 1970s, international concern for high energy consumption and resources shortage began to grow. And for the last 5 years, the worldwide debate on mitigation of GHG emissions and gradual replacement of fossil fuels with renewable energy sources has been in full swing. As the building sector accounts for close to $40 \%$ of the world's primary energy use and $24 \%$ of GHG emissions, it provides great potential for energy savings and deep emission cuts.

All these issues as well as the fact that this sector is marked by longevity, drive research continuously towards more energy efficient building design. However, the energy statistics actually indicate that between 1971 and 2007 total energy consumption in the building sector grew by $1.6 \%$ a year [1]. Of course, this growth could be even higher if not for the incremental increase in energy efficiency. Nevertheless, if we look on the rapid expansion of the built environment and the ownership of energy-consuming equipment, the energy efficiency measures alone could not be sufficient. Therefore, one of the realistic solutions to reverse the trend of buildings' high energy use is a relatively new concept of a building that both consumes energy and generates energy from renewable energy sources with the main goal of reaching balance between them; hence it can be named a Zero Energy Building (ZEB). Moreover, this type of building not only contributes to the decrease of energy consumption in the building sector, but also by producing energy from renewable sources, it can increase the share of renewable energy sources in the national or even international energy consumption-production balance.

\subsection{Confusion versus actions}

When this $\mathrm{PhD}$ project has started in fall 2008, the period when "ZEB talk" began to evolve into an international discussion, the main issue at that time was the lack of a commonly accepted understanding of the Zero Energy Building concept. In the existing literature, the ZEB concept was described with a wide range of terms and expressions, and although all approaches were built on the same "zero" framework, they all had their particularities. One of the first authors, who highlighted this problem internationally were Torcellini et al. [2]:

"Despite the excitement over the phrase "zero energy," we lack a common definition, or even a common understanding, of what it means. (...) A zero energy building can be defined in several ways, depending on the boundary and the metric. Different definitions may be appropriate, depending on the project goals and the values of the design team and building owner. For example, building owners typically care about energy costs. Organizations such as DOE are concerned with national energy numbers, and are typically interested in primary or source energy. A building designer may be interested in site energy use for energy code requirements. 
Finally, those who are concerned about pollution from power plants and the burning of fossil fuels may be interested in reducing emissions. (...) Consistent ZEB definitions are needed for those who research, fund, design, and evaluate ZEBs."

Taking into consideration the above mentioned different interests Torcellini et al. have proposed the following four ZEB definitions:

- "Net Zero Site Energy: A site ZEB produces at least as much energy as it uses in a year, when accounted for at the site.

- Net Zero Source Energy: A source ZEB produces at least as much energy as it uses in year, when accounted for at the source. Source energy refers to the primary energy used to generate and deliver the energy to the site. To calculate a building's total source energy, imported and exported energy is multiplied by the appropriate site-to-source conversion multipliers.

- Net Zero Energy Costs: In a cost ZEB, the amount of money the utility pays the building owner for the energy the building exports to the grid is at least equal to the amount the owner pays the utility for the energy services and energy used over the year.

- Net Zero Energy Emissions: A net-zero emissions building produces at least as much emissions-free renewable energy as it uses from emissions-producing energy sources."

This diversity of ZEB definitions and the lack of a commonly accepted one, which can be applicable for all situations, can often lead to many misunderstandings and hinder further development of the ZEB concept [3-10]. And, even the Internet encyclopaedia Wikipedia [11], seen as a very unscientific source, indicates that there is number of definitions of this building concept with particular differences between them.

Regardless of these concerns and discussions, the ZEB concept has very quickly gained international attention. A number of national and international research programmes started to focus on investigating and implementing the ZEB concept in real life, i.e., the IEA SHC Task 40 / ECBCS Annex 52 "Towards Net Zero Energy Solar Buildings (NZEBs)" [12], Strategic Research Centre on Zero Energy Buildings in Denmark [13], The Research Centre on Zero Emission Buildings (ZEB) [14] in Norway and Zero Carbon Hub [15] in the United Kingdom. According to a map of international Net ZEBs and plus energy houses [16], there are already about 300 buildings/projects around the world designed according to the Zero Energy Building concept, although clear and consistent definition as well as robust "zero" calculation methodology are yet not given. Finally, a relatively good indicator of the ZEB "popularity" is Google search of the phrase "zero energy building", which results in around 1 million links that to a different degree provide us with information related ZEBs.

The confusion over the ZEB definitions did not discourage the policy makers from setting the ZEB requirements as the future building goals. In 2007 within the Energy Independence and Security Act of 2007 (EISA 2007), the United States authorized the Net-Zero Energy Commercial Building Initiative to support the goal of Net zero energy for all new commercial buildings by 2030 . Moreover, U.S. commercial buildings should meet the zero-energy target with $50 \%$ by 2040 and with $100 \%$ by 2050 [17]. At the European level in May 2010, the European Parliament and the Council of the European Union adopted the recast of the Directive on Energy Performance of Building (EPBD) [18] with nearly zero energy building as the future target for buildings: 
"by 31 December 2020, all new buildings are nearly zero energy buildings as defined in Article2(1a),

after 31 December 2018, public authorities that occupy and own a new building shall ensure that the building is a nearly zero energy building (...)"

In the EPBD directive the nearly zero energy building is defined as:

"... a building that has a very high energy performance, as determined in accordance with Annex I. The nearly zero or very low amount of energy required should be covered to a very significant extent by energy from renewable sources including energy from renewable sources produced on-site or nearby"

\subsection{Requirements}

In principle, the "zero" energy goal can be achieved by both a very energy inefficient building with a sufficiently large renewable energy system that meets the annual energy demand, and a very low-energy building that employs small renewable energy production system (RES). Both buildings would be labelled as the Zero Energy Building, but would they indeed be the same "quality" ZEBs? Of course not, the one with lower energy consumption and hence smaller RES needed would be of a higher value than the other one. However, the next question is: how far should we go with energy efficiency measures, and when should we start to apply renewable energy technologies? There is no clear answer to this question, because the level of sufficient energy efficiency can differ depending on (1) the optimization criteria, i.e. $\mathrm{CO}_{2}$ emissions or primary energy or cost, (2) the target group, e.g., building owners, policy makers or technology developers, (3) the national building traditions, (4) the age of a building, i.e., newly constructed or renovated and finally (5) the type of a building, i.e., residential or non-residential.

The issue of various approaches towards the development of minimum energy efficiency levels included in the building codes has been discussed in Europe for a long time. This results that the latest EPBD recast [18] sets uniform criteria and obligates all the Member States to ensure that the minimum energy performance requirements for buildings are defined:

"...with a view to achieving the cost-optimal balance between the investments involved and the energy costs saved throughout the lifecycle of the building."

Moreover, as indicated by Jaffe and Stavins [19] among many others, a possible source of market failure of an energy-conservation technology is when the users' perspective is not included in decisions related to energy efficiency. Moreover, according to Nair et al. [20], a factor as cost can be an obstacle for users when buying environmental- or climate-friendly products. Therefore, as ZEB is a relatively new and not fully developed concept, it is crucial for its future successful adoption that we investigate a cost-optimal combination of energy efficiency measures and renewable energy sources from the economy perspective of a private building owner.

\subsection{Danish Zero Energy Building: BOLIG+}

BOLIG+ is the first demonstration project of a multi-storey, residential Net ZEB in Denmark [21]. The BOLIG+ building concept was initiated in connection with the EnergyCamp05, where a number of representatives from different parts of the building sector were asked to solve the task: How can we develop energy-efficient housing for the growing world population? The 
workshop resulted in the development of a unique and dogmatic approach towards homes of the future. The five dogmas that BOLIG+ building has to fulfil are:

1. Energy neutral on an annual basis, including electricity for appliances

Firstly, the building has to meet the energy frame requirements of energy class 1 defined in the Danish Building Regulations 2008 [22]. Secondly, the household electricity use should also be included in the "zero" energy balance. And finally, the energy delivered to the national grid must be the same quantity and quality as the energy taken from the grid.

2. Intelligent and user-friendly

The building should be equipped with monitoring, data collection, and demand control to facilitate the users to reach the energy neutrality.

3. Flexible in daily use and over time

Firstly, the building inertia should be easy to adapt to the individual and varying needs of diverse user profiles. Secondly, the thermal envelope of a building should easily react and adjust to the building's annual and daily rhythm. Finally, the replacement of different building components should be easy and non-energy-consuming.

4. Good and healthy indoor climate in the house

The focus is put on (1) daylight and artificial light, (2) atmospheric indoor climate, (3) indoor temperature, (4) air quality, (5) acoustics and (6) choice of sustainable and healthy building materials.

5. High architectural quality and adaptation on the local context

The building's design should be in agreement with the surrounding architectural style but at the same time express the period of construction

The winning project building is north-south orientated and consists of one part of 6-stories and a second part of 10 stories. The total area of the building is $7000 \mathrm{~m}^{2}$, where dwellings account for $6790 \mathrm{~m}^{2}$ and the remaining $210 \mathrm{~m}^{2}$ can have a different function depending on need. 


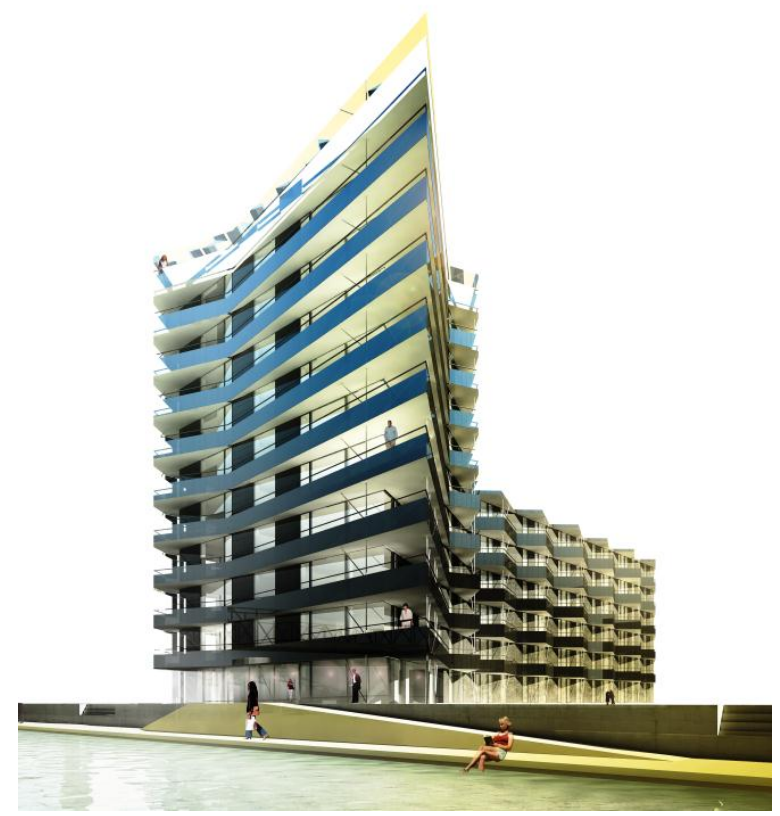

Fig. 1. Animation of the BOLIG+ winning project. $^{l}$

\subsection{Aim and research questions}

This dissertation is based on the fact that the incremental increase in energy efficiency is not sufficient anymore and new concept of energy consuming as well as energy producing building, labelled as Zero Energy Building, is worldwide recognised as a promising solution for decreasing buildings' energy use. As mentioned, in May 2010 the European Commission within the recast of the Energy Performance of Building Directive has set the nearly ZEB as a future building energy. Denmark, as the Member States of the European Union, is obligated to fulfil the goals set in the EPBD recast. This means that by the end of 2018 the requirements for nearly zero energy building should be implemented in the Danish building code. However, before this is done successfully, we need to have a clear understanding of the ZEB concept and comprehensive knowledge about all the issues and ambiguities related to it. Hence the main aim of this dissertation is to contribute to the development of the Danish Zero Energy Building definition.

As mentioned before, this $\mathrm{PhD}$ project started in the period of international confusion and lack of clear understanding of the ZEB concept. Therefore, the first research question was:

1. What are the most important features that describe the Zero Energy Building concept and thus should be implemented in each newly developed ZEB definition?

Furthermore, the EBPD definition of the nearly zero energy buildings points out that this type of buildings should have "a very high energy performance", but it does not set harmonized

\footnotetext{
1 Architects ARKITEMA; Leif Hansen Consulting Engineers A/S; Esbensen Consulting Engineers A/S; FAKTOR 3 Aps, DONG Energy; Thornton Thomassetti; Housing Organisation Ringgården; Bau-How Danmark
} 
minimum or maximum requirements for building energy performance leaving it up to the EU Member States to define these requirements. The cost optimal policy launched by the EBPD does not mention that ZEBs have to be also cost-optimal. However, since the user perspective and the cost of energy-efficiency technologies is so crucial for the successful adaptation of new concepts, the following part of the $\mathrm{PhD}$ work has deployed the Life Cycle Cost (LCC) analysis and taken a view point of private building owner to investigate:

1. What is a better investment: energy efficiency measures or renewable energy sources for a newly constructed multi-storey Net ZEB in a Danish context?

2. What is a better investment: on-site or off-site renewable energy supply option for a newly constructed multi-storey Net ZEB in a Danish context?

3. What is a better investment: to consider or not energy use for household appliances in the "zero" energy balance of a Net ZEB? 



\section{Part I}

The aim of Part I is, through the extensive analysis of existing ZEB definitions and approaches, to determine the most important aspects of the ZEB concept, which should be taken into consideration, before developing a new ZEB definition. Moreover, Part I focuses on giving insight into countries actions towards the fulfilment of future "zero" building goal. Finally, Part I presents different "zero" calculation methodologies from various location worldwide, with highlighting the "gap" between the "known practice" and the respective national building code/standard. 


\section{Zero Energy Building definitions}

Conceptually, the Zero Energy Building can be described as a building with significantly reduced energy demand and the remaining energy offset by production from renewable energy sources. However, with closer insight and thorough analysis, one can notice that this simple ZEB definition does not encompass all aspects of this exiting building concept, and a more detailed description is needed. When looking at the existing ZEB approaches, they are all based on the same energy consuming-producing building concept. However, they all have their particularities and often lack a holistic outline of the ZEB understanding.

\subsection{Description of main ZEB aspects}

The framework of a ZEB definition can be summed up into 4 main aspects: (1) zero balance; (2) renewable energy supply options; (3) energy infrastructure connection; (4) requirements. The following chapter gives an overview of the existing ZEB approaches and discusses pros and cons of the presented options for each ZEB feature.

\subsubsection{Balance}

The key feature of the ZEB concept is that the balance equals zero. And although the term "zero" does not need extra explanation, there are quite large inconsistent in ZEB literature with regards to (1) the unit of "zero", (2) the type of energy use included in "zero", (3) the period over which the "zero" is reached and (4) the way "zero" is calculated. Only the first three points are described in the following chapter, and the fourth point will be elaborated in Chapter 2.

\section{Unit of balance}

By looking at the unit of balance applied in the existing ZEB definitions, there are 5 main units, i.e., final/delivered energy; primary energy; $\mathrm{CO}_{2}$ emissions; exergy and energy cost $[2,6,9,18,23]$. Often, various reasons influence the choice of a specific unit of balance, e.g., (1) the project goals and cost, (2) the intention of investor, (3) the concern about climate change and greenhouse gas emissions [2], (4) the intention of evaluating the building's complete impact on the environment [6] or (5) the requirements of the national building code.

Each of the listed units has its advantages and disadvantages. By far the most acknowledged unit is the energy. It can be chosen between final/delivered and primary energy. As the first option is easy to understand and apply, it does not take into consideration the quality of different energy carries, which can be seen as an unfavourable feature. Therefore, if final energy is applied and ZEB uses more than one energy carrier, e.g., electricity and natural gas, the energy balance need be calculated separately for each carrier. However, this is a rather challenging task to perform. 
Hence, the most frequently applied unit is primary energy, where the quality of energy carriers is accounted for in the primary energy factors (PEFs). Yet, the primary energy is not an issuefree unit. Firstly, the PEFs are determined by policy-makers and are thus sometimes seen as indicators that are only defined in order to promote specific technology solutions. Secondly, although the international PEFs do exist [24], in common praxis the national or even regional values are used, of which calculation procedure can differ from country to country. Thirdly, the grid's PEFs are not constant, but they change over time as the result of changing characteristic of the energy infrastructure, e.g., Denmark prognoses to change the PEF of the district heating grid gradually from factor 1 to 0.8 in 2015 and 0.6 in 2020, and to change the PEF of power grid from 2.5 to 1.8 in 2020 [25].

The balance could be also calculated on basis of $\mathrm{CO}_{2}$ emissions. However, in common praxis, the buildings are evaluated and certificated based on energy performance rather than on emissions performance. Other crediting options are the energy costs and exergy. The first option could be a very 'catchy' advertisement for the ZEB concept and understandable for wide audience but with a major drawback of being very fluctuating. Although, exergy as a unit for calculation allows evaluation of the complete environmental impact of a building [6], it is not well understood outside the academic community and thus it could be difficult for the building industry and policy makers to correctly relate to such thermodynamic concept.

\section{Type of energy use}

Total energy use in the lifetime of a building includes the following types:

- building related: heating, cooling, ventilation, DHW, lighting (nonresidential buildings), pumps and fans and other technical service systems user related: cooking, appliances, lighting (residential buildings)

- construction related: energy use embodied in building materials and installations and energy use for building construction, maintenance, renovation and demolition

Unfortunately, most of the existing ZEB definitions do not specify which energy type is included in the balance $[2,7,9,18,26,27]$. The first ZEB publications from the 1970s and 80s [28-30] indicated that only the thermal energy use of a building was included in the "zero" balance. Probably, it is a consequence of the fact that at that time building energy use was dominated by heating demand. In the recent publication by Hernandez and Kenny [26], the authors suggest that the energy balance should encompass both the energy used by a building during the operation phase and the energy embodied in building construction and systems.

Lack of indication in ZEB definitions of which types of energy are included in the balance is an obstacle for (1) the re-application of the definition and (2) the evaluation of ZEB project designed according to it. Preferably, all types of energy should be taken into account in the "zero" balance and thus the total environmental impact of a building could be evaluated. However, the practice is far from this. The European standards for energy rating and certification method of a building EN 15603 [24] and most of the European building codes [31] focus solely on the energy use related to building operation, and accounting the user and/or construction related energy use is just a voluntary activity. On one hand, neglecting the household electricity use and/or embodied energy is a reasonable solution. The first type of energy is a highly uncertain parameter [32,33], and the latter lacks a commonly accepted framework for calculation and reliable input values [34]. On the other hand, with continuous improvement of energy efficiency, the magnitude of user and construction related energy use 
will grow, and in the future could be at the same or even higher level than the building related energy use.

\section{Balancing period}

In the existing literature, the annual balance is the most favoured balancing period $[5,7,23,27,28,35,36]$. Hernandez and Kenny [26] acknowledge the full life cycle of the building as the most appropriate balancing period, and hence evaluate the true environmental impact of a building. Table 1 gives an overview of possible periods of balance highlighting each option's advantages and disadvantages.

Table 1. Advantages and disadvantage of possible periods of balance

\begin{tabular}{|c|c|c|}
\hline Balancing period & Advantages & Disadvantages \\
\hline $\begin{array}{l}\text { Sub-year: } \\
\text { - } \text { month } \\
\text { - } \text { season: } \\
\quad \text { winter-summer }\end{array}$ & $\begin{array}{l}\text { - } \quad \text { RES dimensioned to better match } \\
\text { the actual energy demand } \\
\text { - } \quad \text { it captures fluctuations of } \\
\text { renewable energy sources }\end{array}$ & $\begin{array}{l}\text { hard to meet zero goal for all } \\
\text { periods due to seasonal } \\
\text { discrepancy between energy } \\
\text { demands and renewable } \\
\text { energy generation }\end{array}$ \\
\hline Year & $\begin{array}{l}\text { - it complies with most building- } \\
\text { related regulation/standards }\end{array}$ & $\begin{array}{l}\text { - impossible to capture } \\
\text { mismatch between energy } \\
\text { demands and renewable } \\
\text { energy production } \\
\text { - } \\
\text { sensitive to user behaviour }\end{array}$ \\
\hline $\begin{array}{l}\text { Operating lifetime, } \\
\text { e.g., } 50 \text { years }\end{array}$ & $\begin{array}{l}\text { - it captures the annual variations } \\
\text { in weather conditions } \\
\text { - it includes possible changes of } \\
\text { occupants } \\
\text { - it accounts start-up period of } \\
\text { building systems }\end{array}$ & - long calculation procedure \\
\hline Full life cycle & $\begin{array}{l}\text { - it takes the embodied energy into } \\
\text { account }\end{array}$ & $\begin{array}{l}\text { - } \text { diversity of boundaries } \\
\text { options: Cradle to Cradle'; } \\
\text { 'Cradle to Grave'; 'Cradle to } \\
\text { Gate' and 'Gate to Grave' } \\
\text { - } \text { lack of robust input data }\end{array}$ \\
\hline
\end{tabular}

\subsubsection{Renewable energy supply options}

The renewable sources can either be available on the site, e.g., sun or wind, or need to be transported to the site, e.g., biomass. With the exception of the ZEB definition given within the EPBD recast “... including energy from renewable sources produced on-site or nearby" [18], most of the existing ZEB definitions do not specify the origin of renewable energy. The publication from 2006 by the American researchers P. Torcellin, S. Pless, M. Deru and D. Crawley [2] can be seen at the first attempt to organize and label the different options of renewable energy supply. They divide the options into two main groups, i.e., the on-site supply and off-site supply, with two smaller sub-groups in each group. In the on-site supply group, they distinguish between the supply within the building footprint and the supply within the building site. And in the off-site supply group, they indicate that the building either uses renewable energy sources available off-site to produce energy on-site, or purchases off-site renewable energy sources. Besides the labelling, they divide the supply option into 5 levels of importance, see Table 2. 
Table 2. ZEB Renewable Energy Supply Option Hierarchy (source: Torcellini et al. [2])

\begin{tabular}{|c|c|c|}
\hline $\begin{array}{l}\text { Option } \\
\text { No. }\end{array}$ & ZEB Supply-Side Options & Examples \\
\hline 0 & $\begin{array}{l}\text { Reduce site energy use through low- } \\
\text { energy building technologies }\end{array}$ & $\begin{array}{l}\text { Daylighting, high-efficiency HVAC } \\
\text { equipment, natural ventilation, evaporative } \\
\text { cooling, etc. }\end{array}$ \\
\hline \multicolumn{3}{|c|}{ On-Site Supply Options } \\
\hline 1 & $\begin{array}{l}\text { Use renewable energy sources available } \\
\text { within the building's footprint }\end{array}$ & $\begin{array}{l}\text { PV, solar hot water, and wind located on the } \\
\text { building. }\end{array}$ \\
\hline 2 & $\begin{array}{l}\text { Use renewable energy sources available at } \\
\text { the site }\end{array}$ & $\begin{array}{l}\text { PV, solar hot water, low-impact hydro, and } \\
\text { wind located on-site, but not on the building. }\end{array}$ \\
\hline \multicolumn{3}{|c|}{ Off-Site Supply Options } \\
\hline 3 & $\begin{array}{l}\text { Use renewable energy sources available } \\
\text { off site to generate energy on site }\end{array}$ & $\begin{array}{l}\text { Biomass, wood pellets, ethanol, or biodiesel } \\
\text { that can be imported from off site, or waste } \\
\text { streams from on-site processes that can be } \\
\text { used on-site to generate electricity and heat. }\end{array}$ \\
\hline 4 & $\begin{array}{l}\text { Purchase off-site renewable energy } \\
\text { sources }\end{array}$ & $\begin{array}{l}\text { Utility-based wind, PV, emissions credits, or } \\
\text { other "green" purchasing options. } \\
\text { Hydroelectric is sometimes considered. }\end{array}$ \\
\hline
\end{tabular}

The renewable energy technologies are most commonly placed within building footprint or site, but other options, i.e., purchase of $\mathrm{CO}_{2}$ credits or green power from nearby/local utility grid are also adopted in order to reach ZEB status [37].

\subsubsection{Energy infrastructure connection}

The phrase "Zero Energy Building" encompasses both off-grid and on-grid cases. The main difference between these two types of ZEBs is the connection to the energy infrastructure. The off-grid ZEB, also named in the literature as "self-sufficient", "autonomous" or "stand-alone", is not connected to any utility grid. All the energy demands are offset by means of renewable energy technologies and energy storage system for periods with peak loads [9,35,38-42]. The on-grid ZEB, also known as "Net zero energy", "grid-connected" or "grid-integrated", has a connection to one or more energy infrastructures. And since the ZEB is an energy producing building, the energy can be transferred from the grid to the building in periods of underproduction, and in periods of overproduction the energy flow is from the building to the grid $[2,7,9,27,35,36,43]$.

Oversized renewable energy producing systems, the need for large storage capacity, energy losses due to storing or converting energy, and backup generator [2,8,38] are the main reasons why the autonomous ZEBs did not gain international attention in favour of grid-connected ZEBs. However, it should be noted that off-grid ZEBs are still designed especially in locations with no energy infrastructure [37].

\subsubsection{Requirements}

Requirements are inherent in the building design, and in the case of ZEBs there are two sets of requirements that are of particular interest, i.e., minimum energy performance level and building-grid interaction. The indoor environment quality (IEQ) requirements are already well defined and describe in international standards, hence they are not further discussed in this chapter. 


\section{Minimum energy performance requirements}

The most logical path towards "zero goal" is firstly to reduce the energy demands by means of energy efficient technologies, and secondly to utilize the renewable energy sources (RES) to supply remaining energy. However, as indicated by Laustsen [9], ZEB can also be a traditional building supplied with very large renewable energy systems, and if these systems deliver the same amount of energy over a year as the energy use in the building, the goal of "zero" is met. And although the ZEB path described by Laustsen [9] is a very uncommon approach, only few of the existing ZEB definitions emphasize the importance of employing energy efficiency measures before utilizing renewable energy sources $[2,21,35]$.

Therefore, in order to eliminate the "inefficient" ZEB cases a fixed value of minimum energy performance level should be included in ZEB definition. However, one should acknowledge that the allowed minimum energy demand requirement depends very much on local context and building type and thus uniform value applicable in all situations is unrealistic.

\section{Building-grid interaction}

As mentioned before, the Net ZEBs are connected to the energy infrastructure. And the general framework for the interaction is: when on-site generation does not meet the loads, Net ZEB imports energy from the utility, and when on-site generation is larger than energy demands, the excess energy is exported back to utility grid. And, on the annual basis the imported energy equals the exported energy.

Most of the existing Net ZEB definitions do not describe the building-grid energy exchange in details, and perceive the utility grid as unlimited energy storage with no losses that can be used whenever building needs it. The exceptions are the definition given by Kilkas [6] and definition of Net ZEB - BOLIG+ [21] where authors at least emphasize that the imported and exported energy has to have the same quality and be of the same usability.

However, the growing interest in Net ZEBs and visions of energy-producing buildings being an important part of energy infrastructure drive research towards a better understanding of building-gird interaction. Currently, the interaction with the electricity grid is given the most attention; however, the heat exchange with district heating grid is also included in Net ZEB agenda. Moreover, today photovoltaic panels (PV) are the most accepted and frequently used technology by the building sector to produce electricity on-site, and thus it is more broadly described and analysed.

The building-grid interaction research can be divided into two main groups.

The first group looks at the problem from the building perspective by investigating how much of on-site electricity generation is actually used to cover building loads, and thus how much electricity building exchanges with the utility grid [44-48]. The studies indicate that the fraction of load covered by on-site generation is very sensitive to:

- $\quad$ time resolution $[44,48]$ : by increasing time resolution the match decreases, e.g., changing the intervals from days to hours the match declines by factor 2 ,

- domestic load profiles [46]: using a heat pump to heat up rooms and domestic hot water instead of gas-fired boiler reduces the match from $42 \%$ to $29 \%$. 
Moreover, as indicated by Voss et al. [44] the match depends on climate zone and building type. The investigations also focus on strategies, which can increase the self-consumption of on-site PV generation, and currently, the battery storage and Demand Side Management (DSM) are the most recognized and effective measures [45,49].

The second group takes the grid viewpoint on building-grid interaction. Lund et al. [50] argue that excess on-site electricity fed in to the power gird should be analysed only from the aggregated level, and implementing battery storage at Net ZEB would only negatively influence the grid. The authors investigate a PV and a wind turbine as on-site electricity technology, and conclude that in the Danish context the 'PV Net ZEB' has a positive influence on the power grid and 'Wind Net ZEB' slightly negative. However, none of these are a problem from the viewpoint of overall electricity supply system. Verbruggen et al. [47] give a closer insight into actual building-power grid connection, and propose 4 indicators that could be used to evaluate the impact of a single Net ZEB on the electricity grid, i.e., one present peak power; peaks above limit; dimensioning rate; and kVA credit. 


\section{Tool for evaluating ZEB definitions}

This part of the $\mathrm{PhD}$ project was developed in close collaboration with the international cooperation project IEA SHC Task 40 / ECBCS Annex 52 'Towards Net Zero Energy Solar Buildings' [12].

\subsection{Description}

The experience and knowledge gained after the study of existing ZEB definitions has led to the conclusions that the development of a unique ZEB definition cannot be based solely on the literature study but requires more active investigation. Therefore, a set of working ZEB definitions has been developed, which translated into calculation methodologies were merged together into one interactive excel-file. The definitions were put together in a way to outline different difficulty degrees of reaching "zero" goal, to test which requirements should be included, and to verify the different options for supplying renewable energy.

Based on the literature review, the grid-connected ZEBs are seen as the future building goal. Hence it was decided that the excel-tool will only encompass Net ZEB definitions. However, at this stage of work, no requirements for building-grid interaction were implemented in the exceltool. The main goal of the tool was to test the different ZEB definitions with various ZEB projects, and thus indicate the direction of further ZEB definition development. The tool included three main sets of Net ZEB definitions with few sub-cases in each. The features of each Net ZEB definition are presented in Table 3. 
Table 3. Characteristics of Net ZEB definitions included in the excel tool.

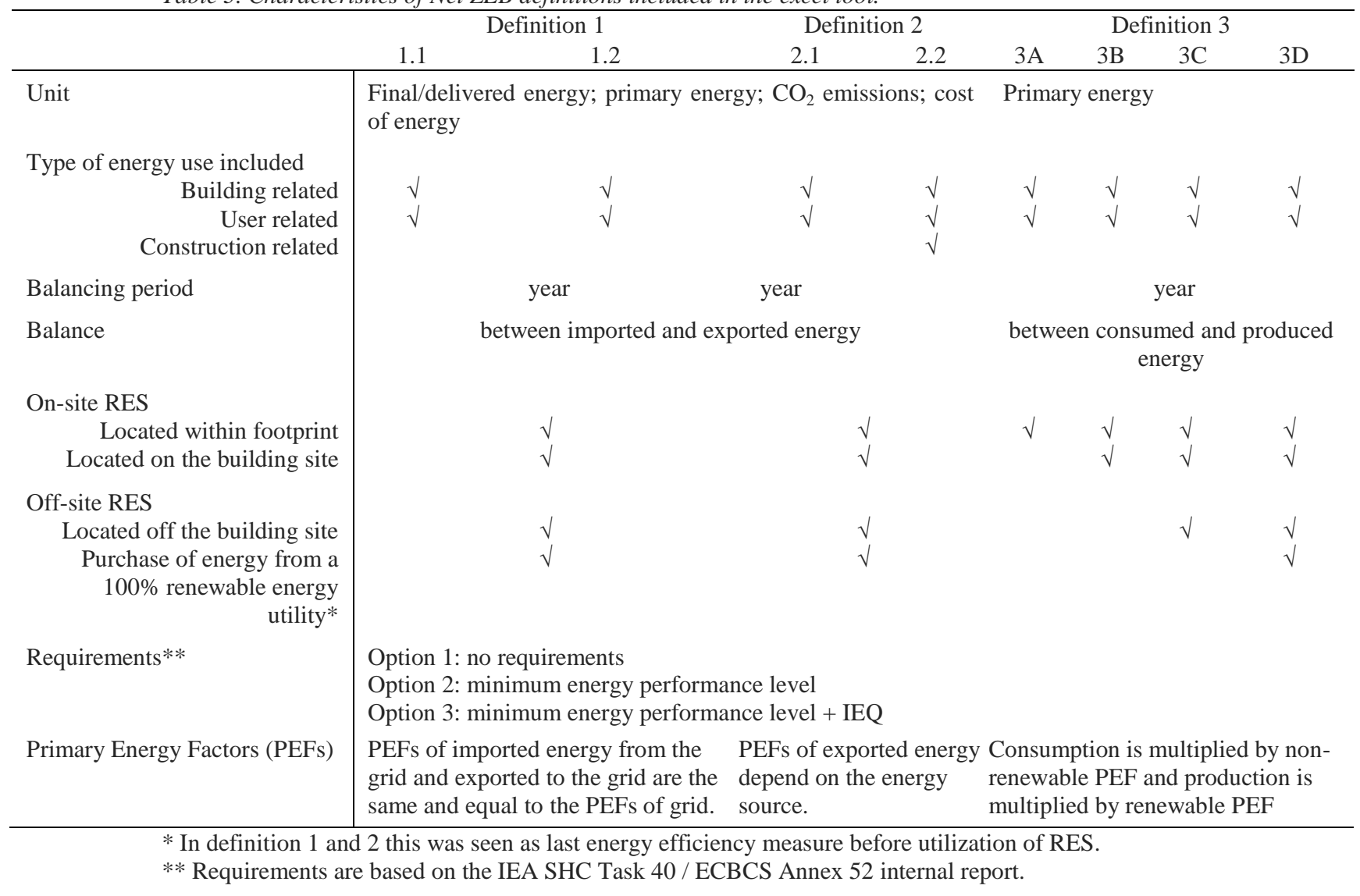

\subsection{Conclusion}

Aside from the known facts that the balance calculated in final/delivered energy is the easiest to fulfil and that in common practice, energy embodied in building construction and systems is not included in energy calculations, the main findings of the evaluation of 8 definitions with Net ZEB projects from different location worldwide are:

(1) in case of primary energy being the unit of balance, application of PEFs of the grid to imported energy and PEFs of renewable energy sources to exported energy results in oversized renewable energy systems and thus large on-site overproduction;

(2) IEQ criteria should not be encompassed in the international Net ZEB definition; they could, however, be included as a part of recommendations or guidelines that facilitate design of high quality ZEBs and

(3) most often only the on-site RES options were utilized for generating energy.

However, the main conclusion is that the future theoretical considerations and expectations of the ZEB concept should go hand in hand with existing "known ZEB calculation practices". With this approach the total potential of ZEB concept will be raped 


\section{National roadmaps towards ZEB and "known ZEB calculation practices"}

Although, ZEBs are yet not explicitly included in any national building code, the Zero Energy Buildings attract a lot of interest from different players in the building sector. Currently, governments and policy makers are determining the mail-stones on the path towards "zero" goal, which is set by the EPBD recast to be in 2020 for all new constructed buildings [18]. Table 4 gives a closer insight into planned changes of the building standards in three EU Member States, Norway and Switzerland. According to the countries' agenda, none of them plan to include the ZEB standard in the building regulations until 2020.

Table 4. Current building code for residential buildings and planned actions towards ZEB [51,52]

\begin{tabular}{|c|c|c|c|c|}
\hline Country & $\begin{array}{l}\text { Current building } \\
\text { regulations }\end{array}$ & $2012-2013$ & 2014-2015 & 2020 \\
\hline Austria & $\begin{array}{l}2010: \\
66,5 \mathrm{kWh} / \mathrm{m}^{2} \text { year (final } \\
\text { energy); } \\
15 \% \text { improvement } \\
\text { compared to } 2007\end{array}$ & & $\begin{array}{l}\text { 2015: } \\
\text { Passive house standard } \\
\text { for new buildings }\end{array}$ & \\
\hline Denmark & $\begin{array}{l}\text { 2010: } \\
52,5-60 \mathrm{kWh} / \mathrm{m}^{2} \text { year } \\
\text { (primary energy) } \\
25 \% \text { improvement } \\
\text { compared to } 2006\end{array}$ & & $\begin{array}{l}\text { 2015: } \\
\text { 30-40 } \mathrm{kWh} / \mathrm{m}^{2} \text { year } \\
\text { (primary energy) } \\
\text { 50\% improvement } \\
\text { compared to } 2006\end{array}$ & $\begin{array}{l}20 \mathrm{kWh} / \mathrm{m}^{2} \text { year } \\
\text { 'nearly zero } \\
\text { energy building' } \\
\text { (primary energy) } \\
75 \% \text { improvement } \\
\text { compared to } 2006\end{array}$ \\
\hline Germany & $\begin{array}{l}\text { 2009: } \\
70 \mathrm{kWh} / \mathrm{m}^{2} \text { year } \\
\text { (primary energy) }\end{array}$ & $\begin{array}{l}\text { 2012: } \\
30 \% \\
\text { improvement } \\
\text { compared to } \\
2009\end{array}$ & & $\begin{array}{l}\text { Zero fossil fuel } \\
\text { building }\end{array}$ \\
\hline Norway & $\begin{array}{l}2010: \\
120 \mathrm{kWh} / \mathrm{m}^{2} \text { year (final } \\
\text { energy); }\end{array}$ & & $\begin{array}{l}\text { Proposal: } \\
\text { Passive house standard } \\
\text { 2014: public buildings } \\
\text { 2015: all buildings }\end{array}$ & $\begin{array}{l}\text { Proposal: } \\
\text { Nearly ZEB }\end{array}$ \\
\hline Switzerland & $\begin{array}{l}\text { 2011: } \\
60 \mathrm{kWh} / \mathrm{m}^{2} \text { year } \\
\text { (primary energy) }\end{array}$ & & $\begin{array}{l}\text { Proposal: } \\
\text { MINERGIE-P } \\
\text { 2015: } 30 \mathrm{kWh} / \mathrm{m}^{2} \text { year } \\
\text { (primary energy) }\end{array}$ & \\
\hline
\end{tabular}

Nevertheless, the zero energy buildings are already being constructed according to unofficial and voluntary understandings and calculation methodologies [37]. The "known practices" are a very useful source of knowledge that correctly applied can facilitate the policy makers in the development of national ZEB definition and requirements. 
The ZEB calculation methodologies, presented in Table 5, were supplied by the participants of the international cooperation project IEA SHC Task 40 / ECBCS Annex 52 'Towards Net Zero Energy Solar Buildings' [12] as one of the project's activity. It should be noted that all of the methodologies focus on grid-connected ZEBs.

\subsection{Austria}

Looking at Table 5, we can conclude that all three supplied calculation methodologies are very much alike, and the unique feature is the components of energy balance. In the methodologies AUT(a) and AUT(b), the balance except building and user related energy consumption, also encompasses so-called "effort for production", which reflects the non-renewable part of on-site RES. It is calculated as on-site energy generation multiplied by non-renewable PEF of applied renewable technology, e.g., non-renewable PEF of photovoltaic is 0,4 [53]. The energy balance in methodology AUT(c) includes only building and user related energy use. The difference between AUT(a) and AUT(b) is that in AUT(a) energy consumption and production are compared on the primary energy level, whereas in AUT(b) they are compared on the final/delivered energy level.

The proposed Net ZEBs calculation methodologies do not comply with the national building code. First, since the building code only defines the methodology for calculating the energy demand of a building, and it fully ignores the possible on-site renewable energy generation issue. Therefore, in the supplied methodologies, the methods for calculating the energy balance have no legal foundations. Second, the building code uses the final energy as the unit whereas the proposed methodologies are based on the primary energy. Furthermore, the delivered methodologies take the total energy demand of the building into consideration including household appliances. The building code for residential buildings focuses only on the demand for heating, domestic hot water and auxiliary and for non-residential on lighting and cooling additionally.

\subsection{Denmark}

Aside from the calculation of energy performance, the Danish proposal also evaluates indirectly the indoor climate in the building by having a special output called "penalty for overheating". This special output represents the electricity demand of a fictive cooling system with a fixed efficiency of 2 that turns on automatically if the indoor temperature is above $26^{\circ} \mathrm{C}$. The only way to control the cooling system is simply by trying to keep the indoor temperatures below $26^{\circ} \mathrm{C}$.

Generally, the proposal for ZEB calculation methodology could be said to be in line with the national building code. There are two major differences: (1) the types of energy use included in the energy balance, (2) the definition of the building site. With the first one, the energy performance framework for residential buildings in the building code covers the total demand for heating, ventilation, cooling and domestic hot water. The supplied calculation proposal goes a step further, and it also takes the energy for household appliances and lightning in the energy balance into account. With the second difference, the renewable energy generation in the Net ZEB calculation proposal can take place within the building's footprint and on site that is directly adjacent to the building. However, in the building code the buildings site also includes the common area that is owned and shared between a cluster of buildings, i.e., 10 residences constructed close to each other and share a common renewable system on a common site around the buildings. 


\subsection{Germany}

The two supplied ZEB calculation methodologies differ greatly from each other. The first one focuses on the annual balance of energy delivered to the building and on the energy feed into the energy infrastructure, and also give multi options for the unit of balance: final/delivered energy primary energy, $\mathrm{CO}_{2}$ emissions and cost of energy. And although Table 5 indicates that the total energy use should be accounted in the energy balance, some builders include all types of energy use in a building and others exclude appliances and plug loads, and thereby only address the building service technology. However, widely applied, this methodology is not in line with the current building code. The second methodology reflects the official building regulation "Energieeinsparverordnung EnEV 2009" [54]; however, it should not be seen as national ZEB calculation methodology. The building code addresses the energy consumption for HVAC, DHW and lighting on a monthly level. On-site generated PV electricity can be subtracted from the building electricity load up to the limit of the monthly consumption. Surplus electricity generated on-site is neglected and considered as part of the grid. So, monthly excess electricity cannot offset demands for other months. Moreover, it is not viable to balance non-electrical demands (gas or wood pellets) with on-site generated electricity from PV, and to integrate other types of energy use in the energy balance. Fulfilment of "zero" goal is almost not feasible considering this framework.

\section{$4.4 \quad$ Norway}

The proposed calculation methodology does not have any particularities. Actually, in general it complies with the building code with only two differences. First, the unit used in the building code is final energy, whereas the proposed methodology includes three units: final energy, primary energy and $\mathrm{CO}_{2}$ emissions. Second, according to the building code, the on-site renewable electricity generation is only accountable for compensating the annual electric specific load, while in the proposed methodology excess feed-in electricity is accounted for achieving "zero" balance. Furthermore, no national scheme currently exists to regulate electricity feed-in tariffs, thus in each case the tariffs have to be agreed with the local electricity provider.

\subsection{Switzerland}

The supplied methodology is actually the only one that accounts for the construction related energy use in the energy balance, in particular the part embodied in the building materials. In that case, there is a set limit of energy in $\mathrm{kWh} / \mathrm{m}^{2} \mathrm{a}$, for the embodied energy under which it is neglected in calculation, but over which the difference between the actual embodied energy and the limit is taken into consideration in the calculations. The exact limit value was still unknown when the methodology was delivered.

The major difference between the proposed methodology and the building regulations is the fact that the Swiss building code focuses only on the heating demand requirements, whereas the ZEB methodology includes the demand for domestic hot water (DHW) and total electricity use as well. The DHW demand and electricity are based on fixed values depending on the building type given by the national Swiss code. By computing the energy balance on the annual basis, the proposed ZEB calculation methodology is in line with the building code. 


\subsection{Discussion and conclusion}

The supplied ZEB calculation methodologies give a significant insight on different possibilities for writing the balance of grid-connected Zero Energy Building. Having their own particularities, which often relate to the national context, we can conclude that most of the supplied methodologies present the same approach towards ZEB calculations. Most favoured is the annual balance between total energy use and on-site renewable energy generation accounted in the primary energy. The exception is the first German methodology, which is based on the balance between energy delivered to the building from the grid and energy feed-in from the building back to the grid. Application of this balance eliminates questions of, e.g., how energy is used in the building and what types of energy use is included in the balance. Indirectly, it also indicates how intensive the interaction is between building and grid.

The difference between the supplied ZEB calculation methodologies and the national building codes vary from country to country. In the cases of the three Austrian methodologies and the first German methodology, there is a distinct lack of cohesion with the building code. In the Danish and Swiss methodologies, the building code can be seen as the departure point for the ZEB calculation. And the last two methodologies, namely the second German and the Norwegian calculations, comply almost fully with building standards 
National roadmaps towards ZEB and "known ZEB calculation practices"

Table 5. Matrix with calculation methodologies' features.

\begin{tabular}{|c|c|c|c|c|c|c|c|c|c|c|c|c|c|c|c|c|}
\hline \multirow[t]{2}{*}{ Country } & \multicolumn{4}{|c|}{ (1) Unit of the balance } & \multicolumn{2}{|c|}{$\begin{array}{l}\text { (2) Period of } \\
\text { balance }\end{array}$} & \multicolumn{3}{|c|}{ (3) Type of energy use } & \multicolumn{2}{|c|}{ (4) Type of balance } & \multicolumn{3}{|c|}{ (5) Renewable supply options } & \multirow[t]{2}{*}{$\begin{array}{l}\text { (6) } \mathrm{PE} \mathrm{\&} \mathrm{CO}_{2} \\
\text { factors }\end{array}$} & \multirow[t]{2}{*}{ (7) Unique features } \\
\hline & $\begin{array}{l}\text { Delivered } \\
\text { energy }\end{array}$ & $\begin{array}{l}\text { Primary } \\
\text { energy }\end{array}$ & $\begin{array}{l}\mathrm{CO}_{2} \\
\text { emissions }\end{array}$ & $\begin{array}{l}\text { Energy } \\
\text { cost }\end{array}$ & Annual & Monthly & $\begin{array}{l}\text { Operating } \\
\text { energy }\end{array}$ & $\begin{array}{l}\text { Total } \\
\text { energy }\end{array}$ & $\begin{array}{l}\text { Energy use } \\
\& \mathrm{EE}^{*}\end{array}$ & $\begin{array}{l}\text { Generation } \\
\text { /Use }\end{array}$ & $\begin{array}{l}\text { Grid } \\
\text { In/out }\end{array}$ & Footprint & On-site & Off-site & & \\
\hline AUT (a) & & $\sqrt{ }$ & & & $\sqrt{ }$ & & & $\sqrt{ }$ & & $\sqrt{ }$ & & $\sqrt{ }$ & $\sqrt{ }$ & & $\begin{array}{l}\text { EN } \\
15603: 2008\end{array}$ & $\begin{array}{l}\text { Energy use embraces also } \\
\text { the effort for on-site } \\
\text { energy generation }\end{array}$ \\
\hline AUT (b) & & $\sqrt{ }$ & & & $\sqrt{ }$ & & & $\sqrt{ }$ & & $\sqrt{ }$ & & $\sqrt{ }$ & $\sqrt{ }$ & & $\begin{array}{l}\text { EN } \\
15603: 2008\end{array}$ & $\begin{array}{l}\text { Energy use embraces also } \\
\text { the effort for on-site } \\
\text { energy generation }\end{array}$ \\
\hline AUT (c) & & $\sqrt{ }$ & & & $\sqrt{ }$ & & & $\sqrt{ }$ & & $\sqrt{ }$ & & $\sqrt{ }$ & $\sqrt{ }$ & & $\begin{array}{l}\text { EN } \\
15603: 2008\end{array}$ & \\
\hline DK & & $\sqrt{ }$ & & & $\sqrt{ }$ & & & $\sqrt{ }$ & & $\sqrt{ }$ & & $\sqrt{ }$ & $\sqrt{ }$ & & Local & $\begin{array}{l}\text { Indirect evaluation of the } \\
\text { indoor climate - penal } \\
\text { electricity for cooling if } \\
\text { indoor temp. above } 26^{\circ} \mathrm{C}\end{array}$ \\
\hline DE (a) & $\sqrt{ }$ & $\sqrt{ }$ & $\sqrt{ }$ & $\sqrt{ }$ & $\sqrt{ }$ & & & $\sqrt{ }$ & & & $\sqrt{ }$ & $\sqrt{ }$ & $\sqrt{ }$ & $\sqrt{ }$ & Local & $\begin{array}{l}\text { External renewable supply } \\
\text { option }\end{array}$ \\
\hline NOR & $\sqrt{ }$ & $\sqrt{ }$ & $\sqrt{ }$ & & $\sqrt{ }$ & & & $\sqrt{ }$ & & $\sqrt{ }$ & & $\sqrt{ }$ & $\sqrt{ }$ & $\sqrt{ }$ & $\begin{array}{l}\text { EN } \\
15603: 2008\end{array}$ & \\
\hline $\mathbf{C H}$ & & $\sqrt{ }$ & & & $\sqrt{ }$ & & & & $\sqrt{ }$ & $\sqrt{ }$ & & $\sqrt{ }$ & $\sqrt{ }$ & & Local & $\begin{array}{l}\text { Special calculation method } \\
\text { of embodied energy }\end{array}$ \\
\hline
\end{tabular}

*Embodied energy 


\section{Concluding remarks Part I}

The study of the existing ZEB definitions has indicated that the following parameters should be elaborated and clearly specified in each of the newly developed ZEB definition: (1) the unit of the balance, (2) the period of the balance, (3) the types of energy use included in the balance, (4) the renewable energy supply options, (5) the connection to the energy infrastructure, (6) the minimum energy performance requirements and (7) the requirements of building-grid interaction. Moreover, the analysis of the literature has also illustrated many possible solutions for defining these parameters, e.g., the unit of the balance can be expressed in final energy, primary energy, $\mathrm{CO}_{2}$ emissions, cost of energy or exergy.

However, the results of the later developed excel-tool with different ZEB definitions have clearly shown that in order to develop a useful and applicable ZEB definition in real projects, some solutions, although having many advantages and being very ambitious, have to be removed from the ZEB agenda at least for the current time being. And, further developments should go hand in hand with existing and used "known ZEB calculation methodologies".

Therefore, when taking the described "known ZEB practices" into consideration, we can already conclude that the future investigations and research should mostly be focused on the grid-connected ZEBs, frequently called Net ZEBs. Due to number of issues, e.g., large storage capacity, the self-sufficient ZEBs should only be designed in the rural locations with no energy infrastructure and thus no possibility for the connection to the utility grid. Moreover, since primary energy is the most commonly used unit, see Table 5, that has the advantage of differentiating between energy carriers, and is also applied in the nearly zero energy building definition given by the European Commission [18], it should be used as the unit of the balance. Furthermore, the balance between energy consumption and renewable energy generation should be evaluated on an annual-basis. It allows for optimization of the building performance for the whole year and not just for a particular season or month, and it is in line with the current Danish building code [25] and the national energy calculation toll (Be10) [55] used for certificating the buildings.

Moreover, Table 5 indicates that both the building and the user related energy use should be included in the "zero" energy balance, and only the on-site renewable energy supply options can be used for generating energy to offset the energy consumption. However, taking into consideration the following facts:

(1) the international and as well Danish energy rating and certification methods of a building [24,25] only account for the energy related to the building operation

(2) the roof and/or façade area is limited, primarily in the dense city areas, the Danish weather conditions

(3) the growing interest and number of wind turbine co-ops, 
it was decided that the energy balance and the renewable energy supply options need to be investigated in more detail before being fixed in the Danish ZEB definition.

None of the presented "known ZEB practices" have included the energy efficiency requirements that need to be fulfilled by the Net ZEB. The lack of these requirements can lead to "inefficient" ZEB design with high energy demands and thus large renewable energy systems but fulfilled "zero" energy goal. As ZEBs represent a new type of buildings that both consume and produce energy, the minimum energy performance requirements could be different from that of a regular building. Therefore, this issue needs to be investigated in more detailed focusing only on the Net ZEBs.

To sum up, in the first part of the PhD thesis three aspects of the future Danish ZEB definition were clarified; in particular (1) the definition applies to grid-connected ZEBs, (2) the unit of the balance is primary energy and (3) the balance is calculated on the annual basis. Moreover, it was decided that the minimum energy performance requirements, renewable energy supply options and the energy types included in the balance will be further investigated in the second part of this $\mathrm{PhD}$ thesis. 


\section{Part II}

As concluded in Part I, not all of the features of the Danish Net ZEB definition can be clarified based solely on the literature review and the studies of the "zero" calculation methodologies. And, the aspects, such as, (1) the minimum energy performance requirements, (2) the renewable energy supply options and (3) the energy types included in the balance, require more detailed analysis reflecting the specific Danish conditions. 


\section{The short story behind}

The Net ZEB concept can be seen as one of the energy-conservation solutions. Unfortunately, the building industry is a complex sociotechnical system, where diverse actors, i.e., policy makers, technology developers, architects, engineers or building owners, have their own approach and understanding of energy efficiency in building design [56]. Moreover, the interest and goal of the various actors can differ, and thus developing a solution that pleases all the groups can be challenging. However, we have to acknowledge that the lack of users' perspective in the design and decision making process of energy-conservation solutions, could be a possible source of market failure of these initiatives [19]. Therefore, without including the private building owners' viewpoint in the developing process of the Net ZEB definition, the Net ZEB potential for significantly reducing the energy use in the building sector will most likely not be fully tapped. Hence the EU targets of $80 \%$ reduction of domestic greenhouse gas (GHG) emission by 2050 compared to 1990 levels will not be met [57].

By taking the viewpoint of the users, we have to accept that a factor such as cost has a significant meaning to this target group. It can often be an obstacle for users when investing money in environmental or climate friendly products [20]. Moreover, building owners or investors often focus only on the up-front investment cost when they decide about, e.g., building design, equipment, energy systems, and they fully neglect future operation or replacement costs [58]. With this praxis, they lack the holistic view of the actual cost of a building, and this can result in rejecting the cost-optimal design.

Taking the above mentioned issues as the departure point, this part of the $\mathrm{PhD}$ thesis deploys a life cycle cost analysis (LCC) and takes the viewpoint of the future Net Zero Energy Building owner to identify the cost-optimal (1) combination between energy efficiency and renewable energy generation (2) renewable energy supply option and (3) energy balance. The results should contribute to the development of the user-friendly Danish Net ZEB definition. It should be emphasized that the aim of this LCC analysis is not to investigate cost advantages of the Net ZEB over a standard building that is designed according to the current Danish building code, but to study the cost-optimal Net ZEB design with the assumption that the Net ZEBs are the current building standard. Moreover, the results of this investigation should be seen as guidelines for the future actions towards sustainable development.

\subsection{Procedure of investigation}

The first step was to calculate the energy use of the reference Net ZEB. Afterwards, the renewable energy system components were sized to generate renewable energy, which offsets consumption, and thus the building meets the zero energy goal on the annual basis. The last step was to calculate the life cycle cost of all alternatives, in order to identify the cost-optimal solution. 


\section{Methodology}

\subsection{Life cycle cost method}

The main goal of the life cycle cost (LCC) analysis is to determine the cost-optimal solution out of different alternatives, which are comparable only with the same economic assumptions, the same study period and service date [59]. The LCC analysis of a building encompasses four types of cost, i.e., investment, operation and maintenance (O\&M), replacement and demolition. Table 6 presents the particular components included in the specific cost types. The lifetime of a building is 50 years and the real interest rate is $\mathrm{d}=3 \%$, hence the annuity factor equals 0.039 . Table 7 summarizes the LCC data used in this analysis.

Table 6. Disposition of components included in particular cost type

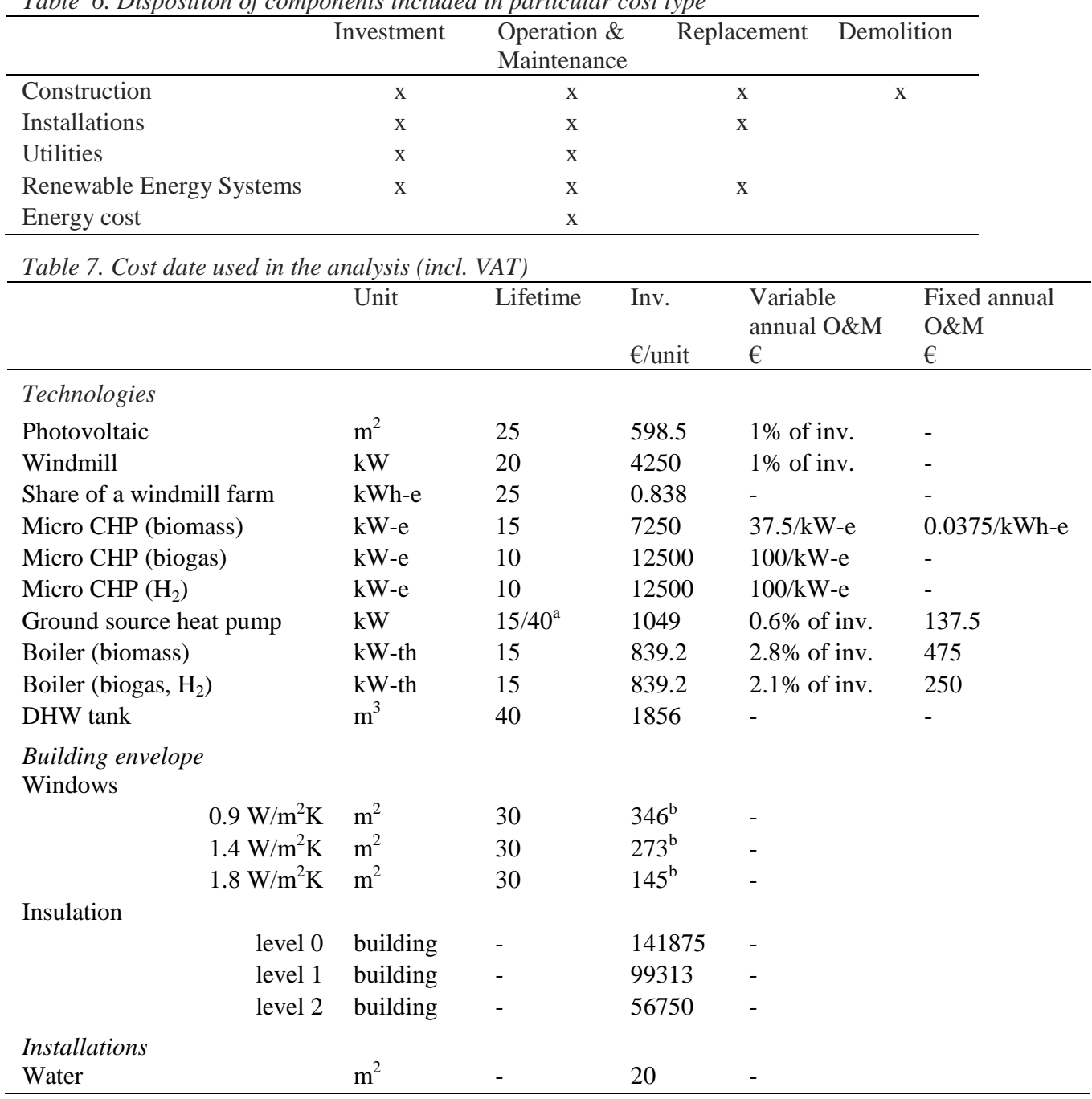




\begin{tabular}{lllll}
\hline Sewage & $\mathrm{m}^{2}$ & - & 10 & - \\
Electricity & $\mathrm{m}^{2}$ & - & 60 & - \\
Floor heating with DH & building & 40 & 59 & $0.5 \%$ of inv. \\
Floor heating with HP/CHP & building & 40 & 70 & $0.5 \%$ of inv. \\
Decentralized ventilation & apartment & 15 & 8392 & $1 \%$ of inv. \\
Utilities & & & & \\
Water & building & - & 1208 & 890 \\
Sewage & apartment & - & 7637 & 92 \\
Electricity & apartment & - & 1485 & 122 \\
Biogas & building & - & - & $193^{\mathrm{c}}$ \\
District heating & $\mathrm{m}^{2}$ & - & 3 & 4.9 \\
& stick & & 1192 & \\
& $\mathrm{~m}$ & 168 & \\
\hline
\end{tabular}

${ }^{\mathrm{a}} 60 \%$ of investment for 15 years lifetime and $40 \%$ of investment for 40 years lifetime

${ }^{\mathrm{b}}$ The cost difference of windows with various U-values based on Velfac price difference, and not the actual cost.

${ }^{c}$ annual consumption over $200 \mathrm{~m}^{3}$

For the on-site renewable energy supply options, the interaction between the Net ZEB and the power grid is based on the net-metering agreement. When, the annual electricity export is larger than the annual electricity import, a situation of plus energy building, the excess feed-in electricity is priced with feed-in tariff. For the off-site renewable energy supply options, there are two different tariffs for imported and exported electricity. Table 8 shows the prices of electricity, district heating and fuel and Table 9 presents the feed-in tariffs for on-site and offsite RES.

\section{Table 8. Energy cost}

\begin{tabular}{|c|c|c|}
\hline & Unit & $€ /$ unit \\
\hline Electricity & $\mathrm{kWh}$ & 0.238 \\
\hline Green electricity & $\mathrm{kWh}$ & 0.239 \\
\hline District heating & $\mathrm{kWh}$ & 0.082 \\
\hline Biogas & $\mathrm{m}^{3}$ & 0.639 \\
\hline Biomass & GJ & $15.751^{\mathrm{a}}$ \\
\hline Hydrogen & $\mathrm{m}^{3}$ & $1.172^{\mathrm{a}}$ \\
\hline \multicolumn{3}{|c|}{${ }^{\mathrm{a}}$ including transport to the building site } \\
\hline \multicolumn{3}{|c|}{ Table 9. The overview of the feed-in tariffs } \\
\hline & Unit & $€ /$ unit \\
\hline PV, MicroCHPs & $\mathrm{kWh}$ & $0.238 / 0.0567^{\mathrm{a}}$ \\
\hline Windmill & $\mathrm{kWh}$ & 0.0546 \\
\hline Share of windmill farm & $\mathrm{kWh}$ & $0.0445^{\mathrm{b}}$ \\
\hline
\end{tabular}

${ }^{\mathrm{a}} 0.238$ tariff according to net-metering agreement, 0.0567 tariff applied after for the excess exported electricity

${ }^{\mathrm{b}}$ tariff is reduced by O\&M cost of the windmill farm

\subsection{Reference Net Zero Energy Building}

The reference Net ZEB is a multi-storey residential building located in Denmark. The building is north-south orientated and consists of one part of 6-stories (18.6 m in height) and a second part of 10 stories ( $30.9 \mathrm{~m}$ in height), see Fig. 2. The building footprint and total area is $824 \mathrm{~m}^{2}$ and $7000 \mathrm{~m}^{2}$, respectively. The Net ZEB is designed for 180 occupants (60 apartments). 

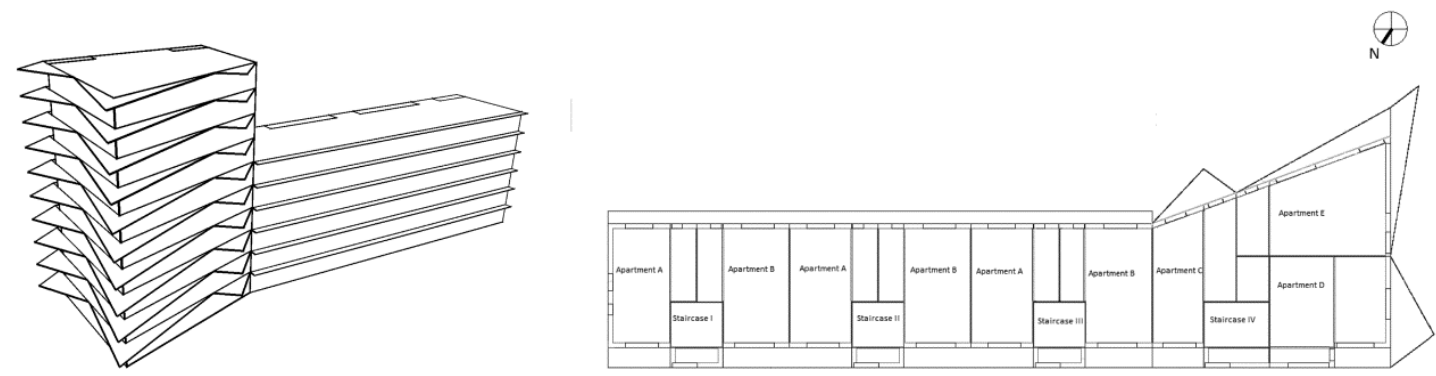

Fig.2. Sketch and floor plan of the reference Net ZEB

The energy use of the building is simulated in dynamic simulation tool BSim [60]. Being a transient model, the Net ZEB hourly profiles of occupancy and household electricity use (including appliances and lighting) are implemented in the BSim model of the Net ZEB. The domestic hot water (DHW) usage is not integrated into BSim; therefore, the DHW profiles and corresponding heat demand are computed separately, and later added to the simulation results. All profiles are defined based on the profiles developed using measured data at Aalborg University [61].

\subsection{Minimum energy performance requirements}

The three energy performance levels included in the LCC analysis are defined to follow the Danish building regulations BR10 [25]. Level 2 corresponds to the currently in force minimum energy performance requirements. Level 1 and level 0 reflect the low-energy class 2015 and class 2020, respectively. Table 10 provides an overview of the particular energy requirements of the three levels for the reference Net ZEB and corresponding typical U-values of the envelope construction.

Table 10. Energy performance requirements and U-values

\begin{tabular}{lllll}
\hline & $\mathrm{Unit}$ & $\mathrm{Level} 2$ & Level 1 & Level 0 \\
\hline Energy frame & $\mathrm{kWh} / \mathrm{m}^{2}$ per year & 52.7 & 30.1 & 20 \\
External wall U-values & $\mathrm{W} / \mathrm{m}^{2} \mathrm{~K}$ & 0.29 & 0.2 & 0.1 \\
Floor U-values & $\mathrm{W} / \mathrm{m}^{2} \mathrm{~K}$ & 0.19 & 0.13 & 0.08 \\
Roof U-values & $\mathrm{W} / \mathrm{m}^{2} \mathrm{~K}$ & 0.19 & 0.13 & 0.07 \\
Window U-values & $\mathrm{W} / \mathrm{m}^{2} \mathrm{~K}$ & 1.78 & 1.4 & 1.0 \\
\hline
\end{tabular}

According to BR10 [25], the primary energy consumption for new residential buildings must include energy for heating, cooling, domestic hot water ventilation, and auxiliary energy. This requirement is followed in the analysis when defining the level of energy performance of the building. However, for the further analysis and for the dimensioning of the energy supply systems, the total primary energy use of the building is taken into consideration, including energy use for appliances and lighting.

\subsection{Alternatives of renewable energy supply systems}

$\boldsymbol{P V}$-HP: Building with on-site photovoltaic installations and a ground source heat pump. The heat pump unit supplies $100 \%$ of the peak heat demand. PV is sized to meet corresponding electricity demand.

$\boldsymbol{P V}$-MiCHP(biogass): Building with on-site photovoltaic installations and a micro fuel cell biogas CHP. The micro CHPs run with heat demand as priority. The CHP unit supplies $60 \%$ of 
the peak heat demand. The rest is covered by a biogas boiler. Biogas is supplied via a gas pipeline system. PV is sized to meet electricity demand.

$\boldsymbol{P V}$-MiCHP(biomass): Building with on-site photovoltaic installations and a micro Stirling biomass CHP. The micro CHPs run with heat demand as priority. The CHP unit supplies $60 \%$ of the peak heat demand. The rest is covered by a biomass boiler. Biomass is transported to the building site. PV is sized to meet electricity demand.

$\boldsymbol{P V}$-MiCHP( $\left.\boldsymbol{H}_{2}\right)$ : Building with on-site photovoltaic installations and a micro fuel cell CHP fuelled with hydrogen. The micro CHPs run with heat demand as priority. The CHP unit supplies $60 \%$ of the peak heat demand. The rest is covered by a boiler. Hydrogen is transported to the building site. PV is sized to meet electricity demand.

$\boldsymbol{P V}-\boldsymbol{D H}$ : Building with on-site photovoltaic installations and connection to the district heating grid. The PV installation is sized to offset heat consumption from district heating.

WM-HP: Building with off-site windmill and a ground source heat pump. The heat pump unit supplies $100 \%$ of the peak heat demand.

SofW-HP: Building owning share of a windmill farm and a ground source heat pump. The heat pump unit supplies $100 \%$ of the peak heat demand.

$\boldsymbol{E} \boldsymbol{l}_{100 \%}-\boldsymbol{H P}$ : Building connected to power grid, which in $100 \%$ is supplied with renewable energy sources and a ground source heat pump. The heat pump unit supplies $100 \%$ of the peak heat demand.

$\boldsymbol{W}$-DH: Building with off-site windmill and connection to the district heating grid. The windmill is sized to offset heat consumption from district heating.

SofW-DH: Building owning share of a windmill farm and with connection to the district heating grid. The share of wind farm offsets also heat consumption from district heating.

Table 11. Efficiencies of technologies applied in the analysis

\begin{tabular}{lccc}
\hline \multicolumn{1}{l}{ Technologies } & Heat & Electricity & COP \\
\hline Photovoltaic & - & $0.075^{\mathrm{a}}$ & - \\
Ground source HP $_{\text {MiCHP }_{\mathrm{BM}}}$ & - & - & $3.0-4.0^{\mathrm{b}}$ \\
$\mathrm{MiCHP}_{\mathrm{BioG}}$ & 0.71 & 0.18 & - \\
$\mathrm{MiCHP}_{\mathrm{H} 2}$ & 0.6 & 0.3 & - \\
Boiler (biogas, $_{2}$ ) & 0.45 & 0.45 & - \\
Boiler (biomass) & 1 & - & - \\
\hline${ }^{\mathrm{a}} 0.1$ efficiency of PV panels and 0.75 efficiency of the building integrated PV (BIPV) system \\
${ }^{\mathrm{b}}$ the COP changes depending on the season, and it varies between 3 and 4
\end{tabular}

\subsection{User profiles}

Table 12 presents the five scenarios of user profiles included in the analysis of a cost-optimal energy balance. The energy use for appliances and lighting is developed based on the measurements described by Petersen et al. in [33] and domestic hot water use is taken from the investigations presented in by Jensen et al. in [61]. 
Table 12. Overview of five scenarios of user profiles

\begin{tabular}{llll}
\hline No. & Profiles & $\begin{array}{l}\text { Appliances + lighting } \\
\text { kWh/apartment per year }\end{array}$ & $\begin{array}{l}\text { Domestic how water } \\
\text { 1/person per day }\end{array}$ \\
\hline 1 & Very low & 744 & $30.0 / 19.8^{\mathrm{a}}$ \\
2 & Low & 1155 & $30.0 / 19.8^{\mathrm{a}}$ \\
3 & Medium & 1725 & $40.0 / 26.8^{\mathrm{a}}$ \\
4 & High & 2061 & $50.0 / 33.0^{\mathrm{a}}$ \\
5 & Very high & 3282 & $50.0 / 33.0^{\mathrm{a}}$ \\
\hline
\end{tabular}

Text in italic represents the base line of user profile

${ }^{a}$ including $33 \%$ reduction due to water saving fixtures 


\section{Results}

The following section presents the results of the cost-optimal analysis. The results are organised in chapters, which directly answer the second, third and fourth research questions of this $\mathrm{PhD}$ project.

\subsection{Energy efficiency versus renewable energy generation}

The cost-optimal combination between energy efficiency and renewable energy generation was investigated gradually with two life cycle cost analyses. The first LCC analysis (later called LCC according to Danish standards) was conducted according to the regulations and requirements of the BOLIG+ competitions. There regulations and requirements complied with the current Danish regulations, which states that only the building site and footprint can be used for placing the renewable energy generating technologies. Hence the study was confined to the on-site RES and the most commonly applied technologies. Therefore, the analysis included only three system alternatives, two of described in chapter 7.4, in particular the PV-HP and the PV$\mathrm{DH}$, and the system combination proposed by the winning project of the BOLIG+ competition, namely a photovoltaic installation in combination of photovoltaic/solar thermal collector and an ambient air / solar source heat pump (PV-PV/T-HP). The second LCC analysis (latter called LCC mix standards) took a broader perspective and encompassed all of the alternatives described in chapter 7.4.

It should be noted that due to net-metering agreement for the on-site RES, the cost of energy is neglected in the LCC according to Danish standards analysis, and thus the results are presented in the present-value terms. As the LCC mix standards analysis encompasses both on-site and off-site RES, the energy cost is included in the cost calculations. The results are presented in the annual-value terms with the assumption that the energy prices follow the global price fluctuations. Thus the predictions of the escalation rate of the future energy prices are eliminated from the analysis

\subsubsection{LCC according to Danish standards}

Table 13 shows that the cost of construction, as expected, decreases with lower thermal properties, i.e., the cost difference is DKK 1.22 M. and DKK 1.93 M. between level 0 and level 1 , and between level 1 and level 2, respectively. The relatively small cost savings are a consequence of a prefabricated modular building construction. Due to the fabricated process of assembling the modules, in this type of construction more than $90 \%$ of the cost is constant between the three energy frames. Therefore, only around $10 \%$, i.e., the cost of insulation and windows, is accountable for the cost difference. The high U-values of the construction result in an increase of energy demand of a building, and thus in an enlargement of the renewable energy system components, such as the heat pump and the PV installation. As a consequence, the cost of RES grows. Taking the PV-HP alternative as an example, the additional cost between level 0 and level 1 is DKK 2.96M., and between level 1 and level 2 is DKK 2.62M. All in all, in a 
consequence of "construction" savings being smaller than additional cost of larger energy systems, the present life cycle cost increases with the higher energy demand.

Table 13. Summary of present life cycle cost of construction and energy supply systems.

\begin{tabular}{lccc}
\hline & $\begin{array}{c}\text { Construction } \\
{[\text { M. DKK] }}\end{array}$ & $\begin{array}{c}\text { Energy Supply Systems } \\
{[\text { M. DKK] }}\end{array}$ & $\begin{array}{c}\text { Total } \\
{[\text { M. DKK] }}\end{array}$ \\
\hline PV-PV/T-HP(2) & 90.72 & 26.62 & 117.33 \\
PV-PV/T-HP(1) & 92.65 & 24.28 & 116.93 \\
PV-PV/T-HP(0) & 93.87 & 21.73 & 115.60 \\
\hline PV-HP(2) & 90.72 & 26.14 & 116.85 \\
PV-HP(1) & 92.65 & 23.52 & 116.17 \\
PV-HP(0) & 93.87 & 20.56 & 114.43 \\
\hline PV-DH(2) & 90.72 & 27.23 & 117.95 \\
PV-DH(1) & 92.65 & 24.57 & 117.22 \\
PV-DH(0) & 93.87 & 21.75 & 115.62 \\
\hline
\end{tabular}

Moreover, the robustness of the LCC results were verified by three scenarios of the PV and $\mathrm{PV} / \mathrm{T}$ prices, see Table 14. Fig. 3 shows that the results are robust for reduction of the PV and $\mathrm{PV} / \mathrm{T}$ costs by $25 \%$. By decreasing the costs by $50 \%$, the trend of higher present life cycle cost for Net ZEBs with higher energy use disappears, and the costs have a more flat distribution. The trend changes when the price of $1 \mathrm{~m}^{2} \mathrm{PV}$ and $\mathrm{PV} / \mathrm{T}$ is reduced by $70 \%$, because the net savings due to lower thermal properties of construction are higher than the cost of additional square meters of PV, and thus the present life cycle cost decreases.

Table 14. PV and PV/T price scenarios

\begin{tabular}{lcclc}
\hline & Ref. & $25 \%$ reduction & $50 \%$ reduction & $70 \%$ reduction \\
\hline $\mathrm{PV}$ & 3588 & 2691 & 1794 & 1076 \\
$\mathrm{PV} / \mathrm{T}$ & 10400 & 7800 & 5200 & 3120 \\
\hline
\end{tabular}

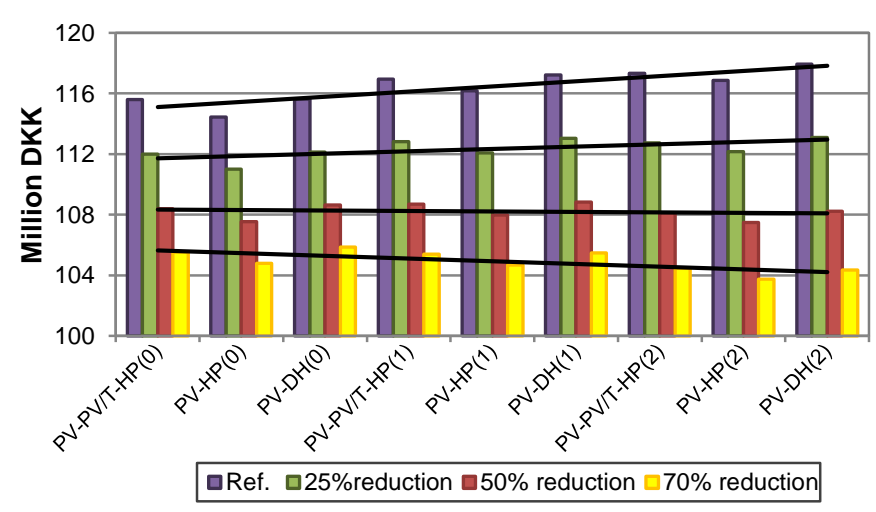

Fig.3. The overview of the present life cycle cost of the Net ZEB with on-site renewable energy system alternatives for three levels of energy performance requirements and four scenarios of the $P V$ and $P V / T$ panels price.

The trend of the life cycle cost is also unchanged when varying the real interest rates from $1 \%$ to $6 \%$. However, it is clear from Fig.4 that a lower interest rate favours investment in energy efficiency measures, whereas a high real interest rate hampers such initiatives. It should be noted that for a lower interest rate, the present-equivalent value of the total cost increases as the future cost is discounted with lower rate, leading to higher present value of the cost at the year zero. 


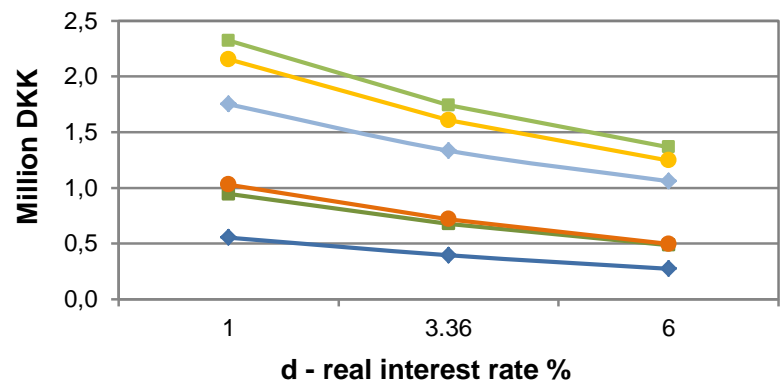

\begin{tabular}{|c|c|}
\hline$\longrightarrow \Delta($ Iv.2-Iv.1)PV-PV/T-HP & )PV-PV/T-HP \\
\hline$\longrightarrow \Delta($ Iv.2-Iv.1)PV-HP & $\longrightarrow \Delta(\operatorname{lv} .1-\mathrm{I}$ \\
\hline$\longrightarrow \Delta($ Iv.2-Iv.1)PV-DH & $\Longrightarrow \Delta($ Iv.1-lv.0)PV-DH \\
\hline
\end{tabular}

Fig.4. The relation between net savings and real interest rate for particular energy systems alternatives. $\Delta(l v .2-l v .1)$ - net savings between energy frame level 2 and $l ; \Delta(l v .1-l v .0)-n e t$ savings between energy frame level land 0 . The real interest rate of $3.36 \%$ is the base line scenario.

\section{Annual cost of $P V$-DH alternative}

The alternative with the district heating - PV-DH proves to be the most costly alternative for all three energy frames. This is a consequence of current accounting method used by the supplying companies. The current tariff constitutes a part that reflects the actual heat consumption (DH variable), and a part that depends only on the size of a building ( $\left.\mathrm{DH} \mathrm{m}^{2}\right)$. As illustrated in Fig. 5 , the constant fee is a significant part of the total annual payment for all 3 cases, and its share grows while the heat demand decreases, such as, $45 \%$ - PVDH(2), 53\% - PV-DH(1), and 64\% $\mathrm{PV}-\mathrm{DH}(0)$. As a consequence, the actual cost of $1 \mathrm{kWh}$ of heat differs between the cases. It is calculated as the ratio between total annual district heating cost and annual heat consumption, and it is DKK/kWh: 0.579 - PV-DH(0), and 0.444 - PV-DH(1), 0.384 - PV-DH(2).

As a result of these variations, new calculation with an alternative tariff is proposed. The tariff depends only on the actual heat consumption, and is the combination of constant and variable fee (DH new tariff). It is calculated to be $0.297 \mathrm{DKK} / \mathrm{kWh}$. In Fig. 5 the green column represents the annual cost of district heating based on the 'DH new tariff'. By eliminating the constant fee, the cost is reduced for all three energy frames by a factor 1.3 for the PV-DH(2), by 1.5 for the PV-DH(1), and by 1.9 for the PV-DH(0). By applying the proposed 'DH new tariff', the total life cycle cost of the PV-DH alternatives decreases, and this system proves to be the most cost-optimal for both level 1 and level 0 energy frames.

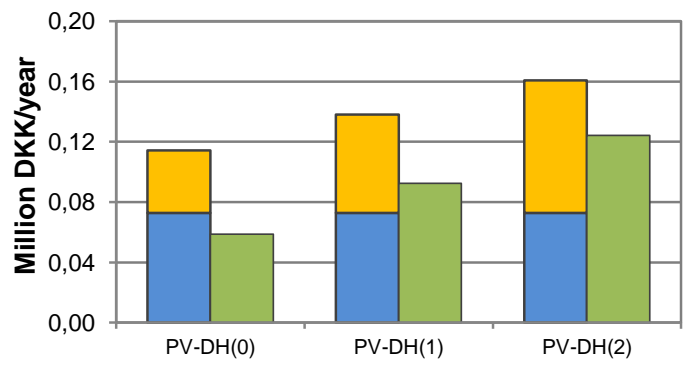

$\square D H\left(m^{2}\right) \quad \square D H$ variable $\quad \square D H$ new tariff

Fig.5. The annual operation and maintenance cost of district heating with current accounting method and newly proposed method. $\mathrm{DH} \mathrm{m}^{2}$ - annual constant fee; DH variable - annual variable fee; DH new tariff - annual new tariff 


\subsubsection{LCC mix standards}

With regard to the on-site RES, the results of the second LCC analysis correspond with the outcome of the first LCC study that the investment in energy efficiency is more cost-effective than investment in renewable technologies, with the exception of the PV-MiCHP(biomass), see Fig. 6. However, Fig. 6 shows that the annual costs of the off-site RES options increase with significant reduction of the energy use. It can be explained by looking at the marginal costs of energy efficiency and the marginal benefits due to smaller renewable energy systems. The marginal benefit is calculated by taking the cost of technologies and fuel into consideration. The electricity cost is taken into account only for the $\mathrm{El}_{100 \%}-\mathrm{HP}$ system, as the green electricity is seen as renewable energy supply option. The improvement of space heating demand by 10.4 $\mathrm{kWh} / \mathrm{m}^{2}$ per year is achieved with a marginal cost of $0.18 € / \mathrm{kWh}$ and further reduction by 7.3 $\mathrm{kWh} / \mathrm{m}^{2}$ requires additional cost of $0.16 € / \mathrm{kWh}$. For all on-site renewable energy systems, expect PV-MiCHP(biomass) described later in the paragraph, the corresponding marginal benefit $(\mathrm{mb})$ is higher than the marginal cost, for example, PV-HP system $\mathrm{mb}_{1-2}=0.19 \mathrm{€} / \mathrm{kWh}$ and $\mathrm{mb}_{0-1}=0.22 € / \mathrm{kWh}$ and $\operatorname{MiCHP}\left(\mathrm{H}_{2}\right)$ system $\mathrm{mb}_{1-2}=1.24 € / \mathrm{kWh}$ and $\mathrm{mb}_{0-1}=1.48 € / \mathrm{kWh}$. The marginal benefit in case of off-site RES is lower than the marginal cost, e.g., and SofW-HP system $\mathrm{mb}_{1-2}=0.06 € / \mathrm{kWh}$ and $\mathrm{mb}_{0-1}=0.08 € / \mathrm{kWh}$ and $\mathrm{W}-\mathrm{DH} \mathrm{mb}_{1-2}=0.13 € / \mathrm{kWh}$ and $\mathrm{mb}_{0-1}$ $=0.08 € / \mathrm{kWh}$.

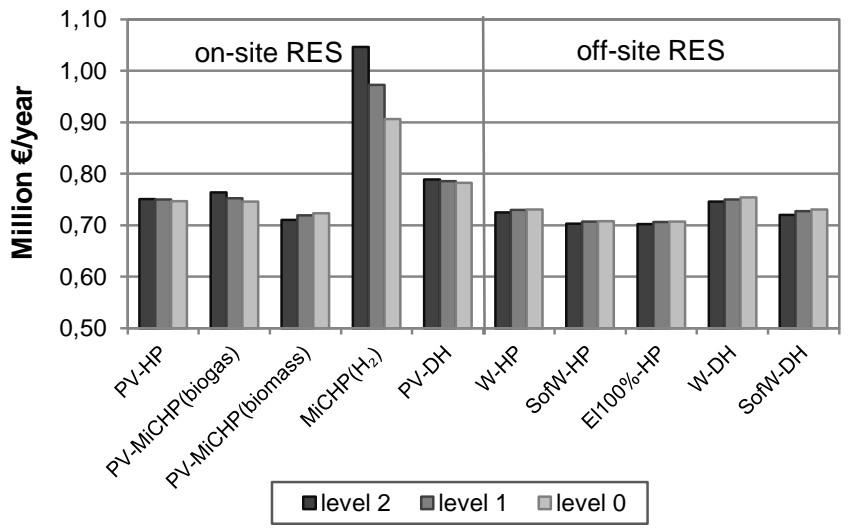

Fig.6. Total annual cost of three levels of energy performance requirements and ten renewable energy supply systems.

As the energy cost was accounted in the LCC mix standards analysis, the investigations included three energy cost scenarios, see Table 15.

Table 15. Energy price scenarios

\begin{tabular}{llllllll}
\hline$€$ /unit & Electricity & Green El. & Biogas & Biomass & \multicolumn{2}{c}{ Hydrogen } & \multicolumn{2}{c}{ District heating } \\
\hline & $\mathrm{kWh}$ & $\mathrm{kWh}$ & $\mathrm{m} 3$ & GJ & $\mathrm{m} 3$ & $\mathrm{kWh}$ & $\mathrm{m}^{2}$ \\
\hline low & 0.071 & 0.072 & 0.192 & 4.721 & 0.352 & 0.051 & 3.05 \\
medium & 0.238 & 0.239 & 0.639 & 15.751 & 1.175 & 0.082 & 4.90 \\
high & 0.405 & 0.406 & 1.086 & 26.781 & 1.998 & 0.112 & 7.43 \\
\hline
\end{tabular}

Text in italic represents the base line energy price scenario

The trend of total annual cost decreasing with more demanding energy frame for on-site renewable energy supply systems and the reverse trend for off-site systems are unchanged for the low energy price scenario. However, for the off-site RES options, the cost differences between the three energy frames increase, hence low energy prices hamper the application energy efficiency measures even more. In high energy price scenario, the total annual costs of the on-site RES have the same overall picture; however, the picture of total annual costs of the 
off-site systems changes. The total annual cost of WM-HP, SofW-HP and $\mathrm{El}_{100 \%}-\mathrm{HP}$ systems have the lowest costs for level 0 energy frame.

\subsubsection{Conclusion}

The analysis has shown that from the private economy perspective and with the current technologies' cost and energy prices, investment in energy efficiency is more cost-effective decision than investment in renewable energy technologies in 5 out of 6 on-site RES options. However, decrease in the PV price changes the life cycle cost trends for the PV-HP and PV-DH alternatives. The off-site RES options have a revers life cycle cost trend, and for all systems, the combination of the least demanding energy frame and high renewable energy generation is the most cost-optimal path towards Net ZEB. Hence, the off-site renewable energy supply options are not in line with the Danish initiatives of further decrease of minimum energy performance requirements beyond 2010 regulations. However, the sensitivity analysis of the energy prices indicated that with the increase of the energy cost, low energy use - and thus small renewable energy generation - is the cost-optimal solution for the off-site RES options as well.

\subsection{On-site versus off-site renewable energy supply options}

The results of the cost-optimal renewable energy supply options are based solely on the LCC mix standards analysis. The renewable technologies are labelled according to the location of the conversion, e.g., inside the boundaries of the building site - on-site, and outside the boundaries - off-site.

\subsubsection{LCC mix standards}

The cost-optimal system within the on-site supply options is the PV-MiCHP(biomass) system, and within the off-site group two systems have almost the same and lowest cost, namely the SofW-HP and the $\mathrm{El}_{100 \%}-\mathrm{HP}$, see Fig. 6. These two systems are also the most cost-optimal systems among all ten renewable energy supply options. When looking only on the electricity generating technologies, namely on the PV, the off-site windmill and the share of a windmill farm, the PV proves to be the most expensive technology for Danish conditions. The life cycle cost of PV generated electricity is $0.473 € / \mathrm{kWh}$, as for the windmill and share of a windmill farm it is $0.160 € / \mathrm{kWh}$ and $0.048 € / \mathrm{kWh}$, respectively. Comparing with the 2010 electricity prices, the $\mathrm{PV}$ electricity is higher by factor 2 . The difference in windmill and share of windmill electricity price is a consequence of longer lifetime of large scale windmills, and the fact that the O\&M of share of windmill farm are accounted for in the reduced feed-in electricity tariff. However, the cost difference between small scale and large scale technologies, see Table 16, clearly indicates that in the Danish context, the windmills should only be implemented in the large scale, while the photovoltaic could be implemented in both scales, since the price of large scale PV installations is not significantly lower than for small scale PV systems.

Table 16. PV and windmill prise overview

\begin{tabular}{|c|c|c|c|c|}
\hline & Unit & \multicolumn{2}{|c|}{ Small scale } & Large scale \\
\hline \multirow[t]{2}{*}{ Photovoltaic } & $€ / \mathrm{W}$ & $>10 \mathrm{~kW}$ & $2.7-5.4$ & $3.2-3.7$ \\
\hline & & $<10 \mathrm{~kW}$ & $2.7-6.7$ & \\
\hline Windmill & $€ / W$ & & & $\sim 1.5$ \\
\hline
\end{tabular}

The total annual cost of Net ZEB heated by biogas or biomass micro CHP indicates that these technologies have potential and could compete with PV and windmills. The micro CHP on hydrogen is much more expensive than the two other micro CHPs. This is due to very expensive hydrogen price of $1.172 € / \mathrm{m}^{3}$. Moreover, it should be noted that the micro CHPs on hydrogen have a major disadvantage of high excess electricity production, which is $60 \%$ - level $0,104 \%$ - level 1 and $166 \%$ - level 2 of the corresponding electricity demand. This electricity is 
feed-in to the power grid; however, the feed-in tariff is only $0.0567 € / \mathrm{kWh}$ due to the rules that all on-site generated electricity above the on-site electricity consumption is not included in the net-metering agreement. In consequence of electricity overproduction, the PV installation is never needed in case of $\operatorname{MiCHP}\left(\mathrm{H}_{2}\right)$. The overproduction of electricity also occurs for level 1 and level 2 of MiCHP(biogas).

The PV-MiCHP(biomass) is a somewhat special case, because energy efficiency is not a costoptimal path towards Net ZEB here, and the total annual cost grows with more demanding energy frame. It is a consequence of a higher share of CHP-electricity in overall renewable electricity generation for the Net ZEB with high energy use, and hence smaller PV area, which results in decreasing cost of renewable energy supplying systems.

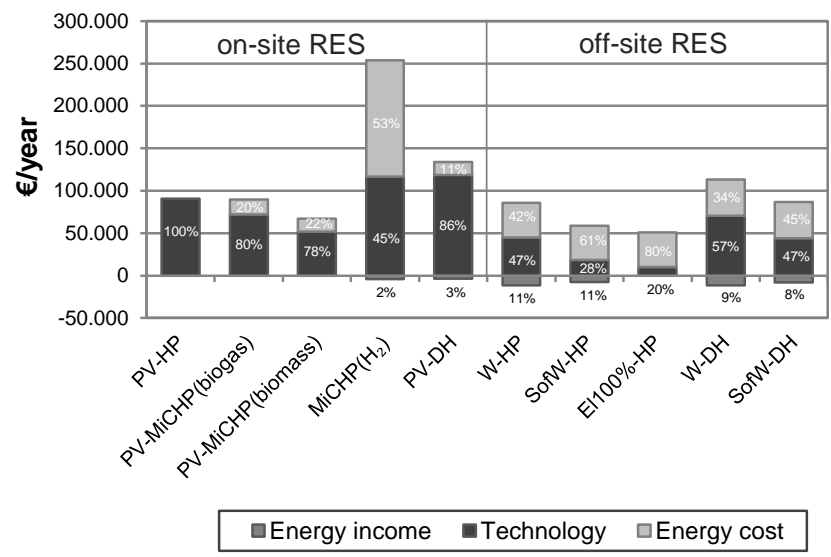

Fig.7. Annual cost of renewable energy systems (technology), fuel, district heating and electricity (Energy cost) and annual income from feeding electricity back to grid (Energy income) of level 0 and ten alternatives of RES.

By excluding the constant costs, namely the cost of construction, installations, subscription fees of electricity, water and sewage utilities, we can evaluate the life cycle cost of particular renewable energy supply systems and associated energy cost (including the cost/benefit of building-grid electricity exchange). Fig. 7 shows that only the PV-HP alternative has no energy cost, and its cost depends only on the technology prices. The reason for this is the net-metering agreement for exporting and importing electricity. The remaining four on-site supply options also exchange electricity applying the net-metering rule. They, however, have additional fuel cost - MiCHPs and district heating cost - PV-DH, and small income due to excess on-site electricity generation. In the case of $\operatorname{MiCHP}\left(\mathrm{H}_{2}\right)$, the fuel cost is actually higher $(53 \%)$ than the technology cost to (45\%). The off-site supply options use a larger part of the annual cost on energy cost, and thus the total annual costs are more sensitive to the energy prices fluctuations than the on-site supply options, see Fig. 8. Moreover, Fig. 8 indicates that for the high energy prices scenario the total annual costs of energy frame level 0 are more even for the on-site and off-site systems. 


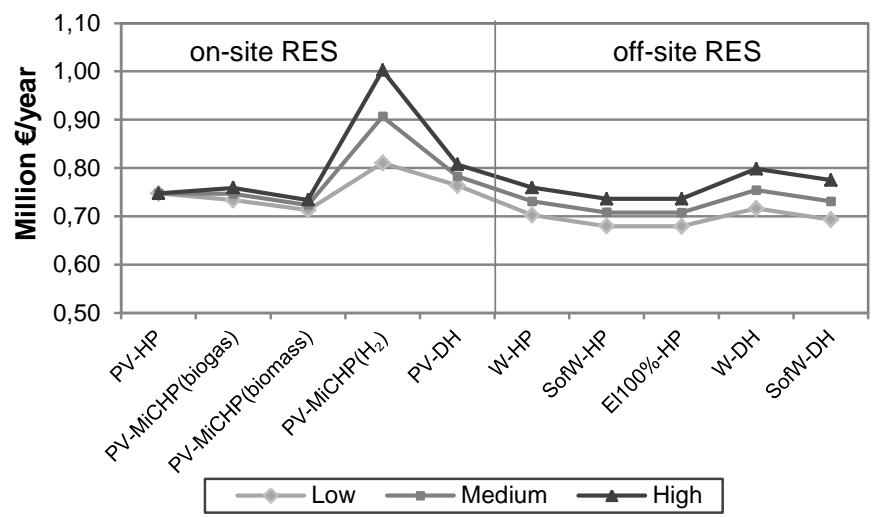

Fig.8. Total annual cost of three energy cost scenarios for level 0 of energy frame and ten renewable energy supply systems.

The variations of the price of $1 \mathrm{~m}^{2}$ of PV indicates that with the cost reduction by $75 \%$, the PVHP results to be the cost-optimal renewable energy supply system for a multi-storey residential Net ZEB, see Fig. 9.

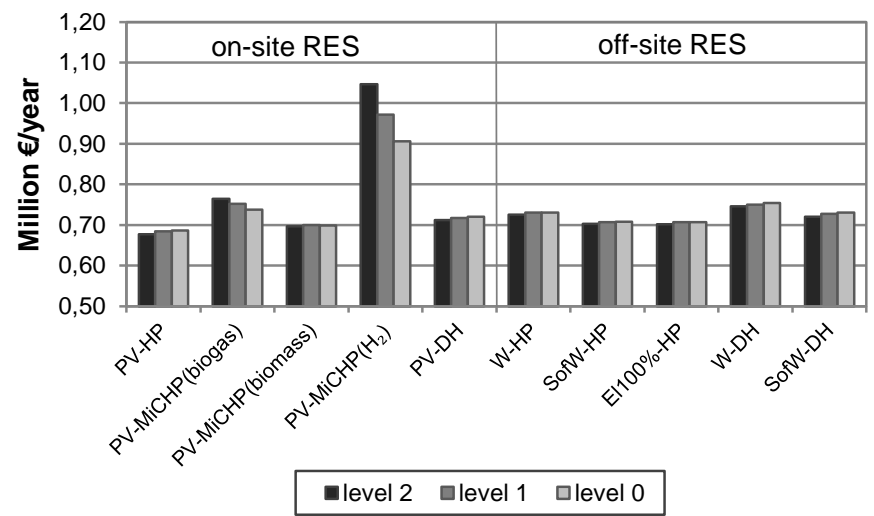

Fig.9. Total annual cost of three levels of energy performance requirements and ten renewable energy supply systems for $75 \%$ reduction of $P V$ price.

\subsubsection{Conclusion}

Generally, the on-site RES systems have a slightly higher life cycle cost than the off-site RES systems, but they have a smaller part of the life cycle cost allocated in the energy cost. Therefore, these renewable energy supply options could be seen as a saver investment from the private economy perspective, because it is more robust for the fluctuations of the energy prices. Moreover, a growing number of the off-site supply options results in a higher share of green energy in the overall energy infrastructure and thus lower primary factors of the grid. Therefore, this presents the issue of how the renewable energy should be accounted for in order to avoid double counting, in the primary energy factors of the grid and in the energy balance of a building.

For the on-site and off-site RES options, the cost-optimal system is PV-MiCHP(biomass) and SofW-HP or $\mathrm{El}_{100 \%}-\mathrm{HP}$, respectively. Moreover, the SofW-HP and $\mathrm{El}_{100 \%}-\mathrm{HP}$ systems are also the cost-optimal systems among all ten renewable energy supply options. However, as presented in Fig. 9, with the PV price reduction by $75 \%$, the PV-HP proves to be the costoptimal system. 
Currently, the micro fuel cells CHPs are a rather costly technology, and have a relatively short lifetime of 10 years compare to other technologies, e.g., PV with lifetime of 25 years. However, it should be noted that fuel cells are still a developing technology, and a significant price reduction is anticipated due to commercialization of the production process [62]. The micro CHP can be a very attractive alternative for the dense city area, where the roof and/or façade areas or solar radiation are limited.

\subsection{Appliances versus no appliances}

The results of the cost-optimal "zero" energy balance are based only on the LCC mix standards analysis.

\subsubsection{LCC mix standards}

The trend of total annual cost decreasing with a stricter energy frame for the on-site RES and the opposite trend for the off-site RES are also maintained for the energy balance excluding appliances. Moreover, the different user profile scenarios do not change the overall picture of the results except the PV-DH alternative and the energy balance without appliances, see Fig. 10.

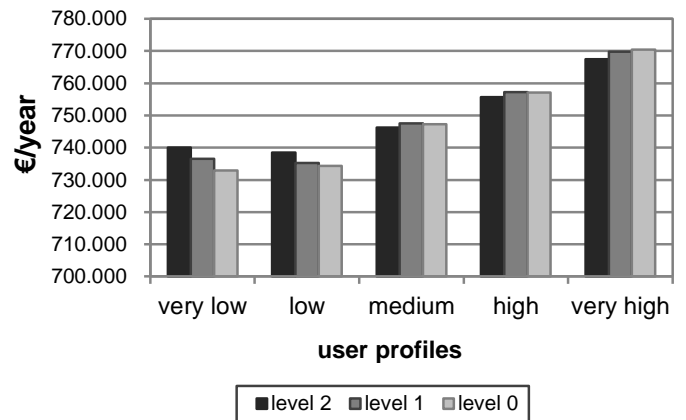

Fig.10. Total annual cost of the PV-DH alternative with the energy balance without appliances for 5 user profile scenarios.

This is a consequence of the assumption that heat from district heating is offset by electricity generated by photovoltaic. Although, in theory there are two PV systems; one covering the electricity demand and the second offsetting the heat from district heating, there is only one point of connection between the Net ZEB and power grid, and hence these two PV systems are merged into one. Therefore, for the "zero" energy balance without appliances, the PV electricity, which should balance the heat, is actually used for household electricity demand. In the case of very low and low user profiles, the total PV electricity exceeds the total electricity demand (including appliances) for all three energy frames, e.g., for the very low profile the relation consumption-production is: $58 \mathrm{MWh} / \mathrm{year}$ - $113 \mathrm{MWh} /$ year (energy frame 2), 58 $\mathrm{MWh} /$ year - $89 \mathrm{MWh} /$ year (energy frame 1), and $57 \mathrm{MWh} /$ year - $71 \mathrm{MWh} /$ year (energy frame $0)$. Thus the Net ZEB does not purchase any electricity from the power grid. As for the medium, high and very high profiles, the consumption is higher than production, and the Net ZEB purchase electricity from the power grid. As a consequence of the total electricity consumption being at the same level for all three energy frames and having a smaller on-site electricity production for more demanding energy frames, the cost of electricity for energy frame 0 are higher than for the two other energy frames. All in all, the savings due to reduced RES components are smaller than additional construction and electricity cost.

The results of the analysis of cost-optimal energy balance are not uniform for all ten system alternatives. 
For the PV-HP and PV-DH alternatives, the "zero" energy balance, which does not account for the user related energy, is always more cost-effective than the balance including all types of energy use. Fig. 11 shows only the results for energy frame (0), but the trends are also similar for the remaining two energy frames. This outcome can be justified by the current energy prices, $1 \mathrm{kWh}$-e from the power grid costs around $0.24 € / \mathrm{kWh}$, whereas $1 \mathrm{kWh}$-e generated by on-site PV costs around $0.47 € / \mathrm{kWh}$.

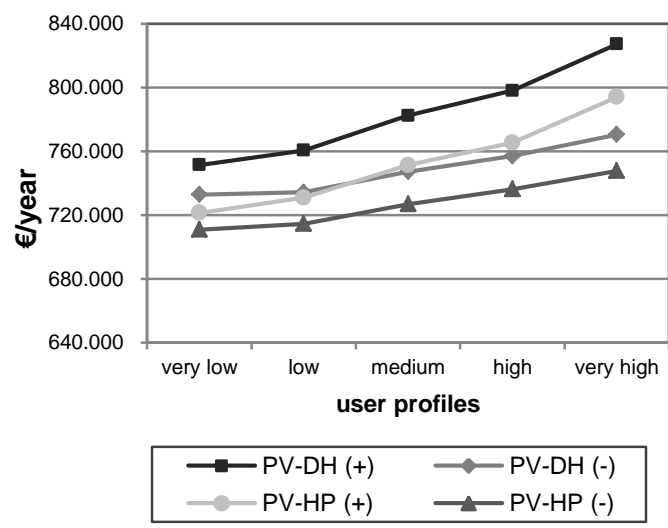

Fig.11. Total annual cost of $P V-H P$ and $P V-D H$ alternatives for the energy frame 0 and five users' profiles scenario. $P V-X(-)$ - energy balance without appliances and $P V-X(+)$ - energy balance with appliances, $X$ stands for $\mathrm{HP}$ or $\mathrm{DH}$.

As indicated in chapter 7.2, the life cycle cost of $1 \mathrm{kWh}$-e generated by an off-site windmill or purchased from a windmill farm is around $0.16 € / \mathrm{kWh}$ and $0.048 € / \mathrm{kWh}$, respectively. Hence, windmill and share of the windmill farm prices are lower than the grid-electricity tariff by factor 1.5 and 5, respectively. Therefore, for these two system alternatives, the "zero" energy balance with household electricity use could be expected to be more cost-effective than the other balance. However, the results of the LCC analysis are opposite, and the cost-optimal is the energy balance without appliances. Three factors are responsible for this: (1) smaller capacities of the renewable energy systems when only offsetting the building related energy use, (2) the need of a power grid for transferring the off-site generated electricity to the building site and (3) the feed-in tariff being significant lower than the grid-electricity tariff, in particular by factor 5.3 for a windmill and by factor 4.3 for a share of windmill farm. Therefore, regardless of the energy balance including or not including the household electricity use, the cost of electricity in both cases is the same, but the life cycle cost of renewable energy systems is lower in the balance without appliances. Hence the total annual cost in the cases not including user related energy use in the energy balance are lower than in the cases including all types of the energy demands in a building.

In the $\mathrm{El}_{100 \%}$-HP alternative, all electricity is purchased from a power grid, which is $100 \%$ supplied with renewable energy sources. Therefore there is no cost difference between the energy balance with or without household electricity use.

The RES alternatives with micro CHPs form a special group of cases. As mentioned in chapter 5, the micro CHPs run with heat demand as the priority, and as described in chapter 7.2 for medium user profile and energy balance including appliances, this type of operation results in overproduction of electricity for the micro CHP on hydrogen and biogas. As the heat demand is constant of both energy balances for particular user profile, the capacity of the micro CHP units are also the same and thus the amount of generated electricity. Therefore, with the assumption that the on-site generated electricity is used to first meet the on-site demand and then the excess amount is exported to the grid, the user related electricity use is offset by on-site renewable 
generation also when being not accounted for in the energy balance. This results that the total annual costs of energy balance with and without appliances are equal, see Table 17. The exception in energy frame 0 for the very high user profile is the example of the total electricity demand being greater than the electricity generation from CHP. Thus, for the energy balance including appliances, a PV installation is added, and for the second balance electricity is purchased from the utility grid. The alternative of the biogas micro CHP has broadly similar results as the hydrogen micro CHP outcome. However, due to electrical efficiency of 0.3 , which is lower than the hydrogen unit, see Table 11, the biogas micro CHP generates less electricity. Hence, for energy frame 0 , the medium user profile and the latter two user profiles, the energy balance without appliances proves to be the more cost-effective solution, see Table 17. Since the biomass CHP has even electrical efficiency of 0.18 , the overproduction of electricity and the same total annual costs of both balances are occurring only for the very low household electricity use and high heat demand, see Table 17. For all other cases, the cost-optimal solution is the energy balance without appliances.

Table 17. Overview of the total annual cost of alternatives with micro CHPs for five user profiles scenarios and all three energy frames. (-) - the energy balance without appliances; (+) - the energy balance with appliances

\begin{tabular}{|c|c|c|c|c|c|c|c|}
\hline \multirow[t]{2}{*}{ User profile } & \multirow[t]{2}{*}{ Energy frame } & \multicolumn{2}{|c|}{$\operatorname{MiCHP}\left(\mathrm{H}_{2}\right)$} & \multicolumn{2}{|c|}{ MiCHP(biogas) } & \multicolumn{2}{|c|}{ MiCHP(biomass) } \\
\hline & & $(-)$ & $(+)$ & $(-)$ & $(+)$ & $(-)$ & $(+)$ \\
\hline \multirow{3}{*}{ very low } & 0 & 896.323 & 896.323 & 729.603 & 729.603 & 690.300 & 692.834 \\
\hline & 1 & 964.482 & 964.482 & 746.042 & 746.042 & 690.232 & 690.232 \\
\hline & 2 & 1.040 .629 & 1.040 .629 & 757.745 & 757.745 & 688.541 & 688.541 \\
\hline \multirow{3}{*}{ low } & 0 & 887.530 & 887.530 & 729.107 & 729.107 & 695.518 & 704.569 \\
\hline & 1 & 954.492 & 954.492 & 745.071 & 745.071 & 694.941 & 701.005 \\
\hline & 2 & 1029.926 & 1029.926 & 756.712 & 756.712 & 689.785 & 691.460 \\
\hline \multirow{3}{*}{ medium } & 0 & 906.333 & 906.333 & 740.782 & 746.185 & 707.085 & 723.241 \\
\hline & 1 & 972.203 & 972.203 & 752.282 & 752.282 & 706.412 & 719.638 \\
\hline & 2 & 1.046 .491 & 1.046 .491 & 763.833 & 763.833 & 701.210 & 710.149 \\
\hline \multirow{3}{*}{ high } & 0 & 928.374 & 928.374 & 750.403 & 758.337 & 715.431 & 735.205 \\
\hline & 1 & 991.930 & 991.930 & 760.671 & 762.814 & 714.484 & 731.385 \\
\hline & 2 & 1.065 .548 & 1.065 .548 & 770.541 & 770.541 & 709.260 & 721.939 \\
\hline \multirow{3}{*}{ very high } & 0 & 915.275 & 922.446 & 765.690 & 793.861 & 731.325 & 769.848 \\
\hline & 1 & 966.572 & 966.572 & 774.416 & 797.412 & 729.759 & 765.722 \\
\hline & 2 & 1.035 .863 & 1.035 .863 & 779.262 & 794.526 & 724.281 & 756.343 \\
\hline
\end{tabular}

Text in italic represents the base line energy price scenario

\subsubsection{Conclusion}

Generally, the "zero" energy balance that does not account for household electricity use results to be the cost-optimal Net ZEB balance for the majority of the RES alternatives with current energy prices and technology cost. Moreover, as indicated by the cost results, high user related energy use is even more in favour of excluding appliances from the "zero" energy balance. This outcome is in line with both the European building energy rating standard [24] and the Danish building code [25], where only calculating the building related energy use is obligatory. However, increase of the energy prices or decrease of the technology cost could change this picture.

Although the life cycle cost of $1 \mathrm{kWh}-\mathrm{e}$ for the off-site systems, such as, a private windmill or a share of a windmill farm, is lower than the price of $1 \mathrm{kWh}$-e bought from the power grid, the necessity of grid-transfer for the off-site generated electricity hampers this cost advantage. 
In case of the CHP units, the cost-optimal "zero" energy balance depends on the relationship between heat demand and total electricity demand. When the total electricity demand is greater than $25 \%$ - biomass unit, $50 \%$ - biogas unit, and $100 \%$ - hydrogen unit of the heat demand then the cost-optimal solution is the energy balance without appliances. 


\section{Concluding remarks Part II}

With the 2010 price level, the life cycle cost results indicate that the path towards a cost-optimal multi-storey residential Net ZEB is different for the two groups of renewable energy supplying options. As the on-site RES are in favour of implementing energy efficiency measures before applying renewable energy technologies, the off-site options do not support this approach and the cost-optimal energy performance requirements are the 2010 requirements. However, either a $50 \%$ decrease of the PV prices or a significant increase of the energy prices would change the picture of the life cycle cost results.

Moreover, the investment in off-site RES is currently a more cost-effective decision from the viewpoint of a private building owner. Nevertheless, the off-site RES options have the disadvantage of having a larger share of life cycle cost dedicated to energy cost and thus being more sensitive to energy price fluctuations.

For both groups of RES, the cost-optimal "zero" energy balance is the balance, which does not account for the user related energy use 



\section{Conclusion}

Today, a large part of the global debate about climate change is dedicated to the building sector and its potential for deep greenhouse gas mitigation and reversion of growing energy consumption. Since buildings are durable and thus the building decisions have long-term consequences, we have to be certain that strategies, which we develop today for future buildings, will tap the existing potential and fully contribute to decrease the world's energy use. With this message, the main goal of this $\mathrm{PhD}$ thesis was to contribute to the development of a clear understanding of the ZEB concept, which is seen as a solution that will not only stop the growing energy consumption of the building sector, but also increase the share of renewable energy source in the overall consumption-production balance.

The detailed study of existing ZEB definitions indicated that the zero energy building type is a complex concept, and one uniform definition applicable in all local contexts is an unrealistic idea. Firstly, there are too many particularities between countries, e.g., climate, local building traditions, national resources, approach and ambitions towards energy efficiency, renewable energy sources and sustainable development. Secondly, there are too many players with different focuses and interests involved in the building sector. Regardless of these differences, in order to avoid misunderstanding each ZEB definition should clearly indicate the following six parameters: (1) the connection or the lack of it to the energy infrastructure, (2) the unit of the balance, (3) the period of the balance, (4) the types of energy use included in the balance, (5) the minimum energy performance requirements (6) the renewable energy supply options, and if applicable (7) the requirements of building-grid interaction.

Further analysis of "known ZEB calculation methodologies" pointed out that due to large storage capacity requirements and oversized renewable energy generating systems, the autonomous ZEBs are outside the scope of ZEB agenda. And, the newly developed ZEB definitions should focus on grid-connected ZEBs - Net ZEBs. The advantage of the Net ZEBs is that, through the connection to the energy infrastructure, they import energy from the grid during the periods of on-site underproduction, and export generated energy during the periods of on-site overproduction. Hence they do not need any on-site storage. As a consequence, they could be seen as the decentralized energy systems, which can, if properly designed, contribute significantly to the national energy system. The results of the analysis showed also that primary energy is the most favoured unit and a year is the most commonly applied period for the "zero" balance. Choosing the primary energy as the unit of balance, we should be aware of the evolution of the energy system towards a $100 \%$ renewable energy source system. Therefore, the future Net ZEB definition should also address this transition, and we could use the electricity trading market, which takes the hour-by-hour energy source mix in the power grid into account, as an inspiration.

The life cycle cost analysis showed that from the private economy perspective with 2010-price level, the off-site renewable energy supply options were found to be more cost-attractive than the on-site energy generating alternatives. However, significant reduction of energy demands, to the level of approx. $20 \mathrm{kWh} / \mathrm{m}^{2}$ per year (primary energy) before application of renewable 
technologies is seen as the most cost-optimal path towards Net ZEB in five out of six on-site renewable energy supply options. For the off-site renewable supply options, the path is opposite. Here, the cost-optimal multi-storey residential Net ZEB should meet only the current in-force energy performance requirements of $52.7 \mathrm{kWh} / \mathrm{m}^{2}$ per year (primary energy). These results indicate that the off-site RES alternatives do not comply with the Danish national plans for incremental sharpening of the minimum energy performance requirements towards "nearly zero energy building" level in 2020.

The analysis also indicated that by having bigger part of the cost allocated in the energy cost, the costs of off-site solutions are more sensitive to the fluctuations of energy prices. Moreover, a growing number of the off-site supply options results in higher share of green energy in the overall energy infrastructure and thus lower primary factors of the grid. Therefore, this presents an issue of how the renewable energy should be accounted for in order to avoid double counting; in the primary energy factors of the grid and then in the energy balance of a building Furthermore, the off-site energy supply systems are assigned more to the particular building owner rather than to the building itself, which means that with a change of the building occupants, the building status of Net ZEB could be change.

Therefore, since the off-site RES options have the cost advantage over the on-site RES alternatives from a private Net ZEB owner's perspective, it is recommended that the Danish Net ZEB definition should only include the on-site options of renewable energy supply. In order to compensate for the cost disadvantage, the on-site RES could be partly subsidised. However, it should be strongly emphasised that this type of financial instruments could only be applied after ensuring that the minimum energy performance requirements are fulfilled.

Furthermore, the LCC analysis revealed that due to current accounting systems, the district heating is a less cost-attractive solution than a ground source heat pump for a private building owner. Therefore, if district heating companies are to compete with the individual heat pumps in supplying heat to future Net ZEBs, a "new tariff" is recommended, which depends solely on the actual building heat consumption,.

The micro Combined Heat and Powers (CHP) units are a very attractive alternative in situations, where the roof and/or façade areas are limited or the solar irradiance is low. With the current level of technology cost, the micro Stirling biomass CHP turned out to be the most costattractive unit for a private Net ZEB owner. The micro fuel cells CHPs are still at the development stage and the technology costs are high. Therefore, compared with the other renewable technologies, micro fuel cells CHPs prove to be an expensive solution to heat the Net ZEBs. Moreover with the Danish feed-in tariff system, significant electricity overproduction with these CHP units is seen as a cost disadvantage.

The analysis of cost-optimal "zero" energy balance indicated that the energy balance, which only accounts for building related energy use, is the most cost-optimal solution. On one hand, this result could be seen as satisfactory because it complies with both European and Danish methodology for energy rating of buildings and with the current praxis. On the other hand, it could be seen as disappointing because with current technology development, user related energy use often becomes larger than the building related and thus a big part of the total energy use of a building is unbalanced with renewable energy generation. Therefore, it is recommended, as with the low-energy building classes, to develop two classes of Net ZEB, i.e., an obligatory class 2 with the "zero" energy balance accounting only for building related energy use and a voluntary class 1 with the "zero" energy balance encompassing both the building and user related energy use. By doing so, engineers, architects etc. will have time to become familiarised with the new idea of accounting total energy use in the energy balance, and with time the Net ZEB class 1 will become obligatory. 
The Net Zero Energy Buildings are an important part of the international roadmap towards a $100 \%$ renewable world. They not only contribute to the decrease of energy use in the building sector, but to the increase of the share of renewable energy sources as well. This PhD project showed that Net ZEB concept can be understood and explained in many different ways, and it identified the path towards a user-friendly Danish Net ZEB definition. Hopefully, the findings of this study will contribute to better understanding of the Zero Energy Building concept. 



\section{Future work}

The study case of this $\mathrm{PhD}$ project is a multi-storey residential Net ZEB constructed from prefabricated modules and located in dense city area. On one hand, the study case of a Net ZEB project could be seen as more challenging and demanding than a single family house. On the other hand, some costs are reduced compared with small scale constructions due to the scale of the project and prefabricated building construction. Therefore, in order to make the results more general, further work is needed to investigate the life cycle cost of other types of Net ZEBs, different types of construction and other locations, e.g. outside the district heating area.

In the LCC analysis, the cost-optimal solutions were studied from a private economy perspective. However, in order to have a complete financial picture, which is a very important for policy making and development of building regulations, a socio-economic analysis should be conducted in order to investigate the cost-optimal solutions from a societal viewpoint.

Moreover, this LCC study did not include any financial incentives or subsidies if a certain energy performance level was reached for a private building owner. Therefore, the next step of the LCC analysis could be to focus on investigating various financial instruments and defining which instruments are the most effective, long-term solutions for promoting high quality Net ZEBs in the private sector,

Furthermore, the percentage of new buildings is small compared with existing building stock, and so we can raise the question of why the focus of this $\mathrm{PhD}$ project was solely on newly constructed Net ZEBs. It is believed that once the feasibility of new building concepts is verified with newly constructed projects, which are significantly less problematic than renovation projects, then the experience, knowledge and lessons learned should be intelligently transferred to the existing buildings. With this approach, the process of implementing new building concepts in real life is much more effective and less time consuming. 



\section{References}

[1] International Energy Agency (IEA), 2010 Energy Technologies Perspectives: Scenarios and Strategies to 2050, OECD/IEA, Paris, 2010

[2] P. Torcellini, S. Pless, M. Deru, D. Crawley, Zero Energy Buildings: A Critical Look at the Definition, ACEEE Summer Stud, Pacific Grove, California, USA (2006)

[3] National Renewable Energy Laboratory (NREL), The Potential Impact of Zero Energy Homes, USA (2006) http://www.toolbase.org/PDF/CaseStudies/ZEHPotentialImpact.pdf (accessed December 2008)

[4] Center for the Built Environment (CBE), Centerline. Getting to zero-energy buildings, USA (2008) http://www.cbe.berkeley.edu/centerline/summer2008.pdf (accessed January 2009)

[5] P.A. Torcellini, D.B. Crawley, Understanding zero-energy buildings, ASHRAE Journal 48 (9) (2006) 62-69

[6] S. Kilkis, A new metric for net- zero carbon buildings, Energy Sustainability Conference, Long Beach, California 2007

[7] M. Noguchi, A. Athienitis, V. Delisle, J. Ayoub, B. Berneche, Net Zero Energy Homes of the Future: A Case Study of the ÉcoTerraTM House in Canada, Renewable Energy Congress, Glasgow, Scotland, July 2008

[8] K. Voss, What is Really New about Zero-Energy Homes? In Proceedings of 12th International Conference on Passive Houses, Nuremberg, Germany, 2008, pp. 187-192

[9] J. Laustsen, Energy Efficiency Requirements in Building Codes, Energy Efficiency Policies for New Buildings, OECD/IEA, Paris, 2008

[10] I. Sartori, , A. Napolitano, A.J. Marszal, S. Pless, P. Torcellini, K. Voss, Criteria for Definition of Net Zero Energy Buildings, In Proceedings of EuroSun 2010: International Conference on Solar Heating, Cooling and Buildings, Graz, Austria, 2010

[11]Wikipedia (2011). http://www.wikipedia.org/ (accessed July 2011)

[12] IEA SHC Task 40 / ECBCS Annex 52 'Towards Net Zero Energy Solar Buildings (NZEBs), http://www.iea-shc.org/task40/index.html (accessed 08.07.2011)

[13] Strategic Research Centre on Zero Energy Buildings, http://www.zeb.aau.dk/ (accessed 08.07.2011)

[14] The Research Centre on Zero Emission Buildings (ZEB), http://www.sintef.no/projectweb/zeb/ (accessed 08.07.2011)

[15]Zero Carbon Hub, http://www.zerocarbonhub.org/ (accessed 08.07.2011)

[16] Map of net zero-energy and energy-plus buildings worldwide http://www.enob.info/en/netzero-energy-energy-plus-or-climate-neutral-buildings-in-the-next-generation-of-electricitygrids/international-projects-on-climate-neutral-living-and-working/ (accessed 01.11.2011)

[17]D. Crawley, S. Pless, P. Torcellini, Getting to Net Zero, ASHRAE Journal 51 (9) (2009) $18-25$

[18] The Directive 2010/31/EU of the European Parliament and of the Council of 19 of May 2010 on the energy performance of buildings, Official Journal of the European Union, 53 (2010)

[19] A.B. Jaffe, R.N. Stavins, The energy paradox and the diffusion of conservation technology, Resource and Energy Economics 16 (1994) 91-122 
[20] Nair G, Gustavsson L, Mahapatra K. Factors influencing energy efficiency investments in existing Swedish residential buildings, Energy Policy 38 (2010) 2956-2963

[21]K.B. Wittchen, J.S. Østergaard, S. Kamper, L. Kvist, BOLIG+ an energy neutral multifamily building, In Proceedings of EuroSun 2010: International Conference on Solar Heating, Cooling and Buildings, Graz, Austria, 2010

[22]Danish Building Regulations 2008, http://www.ebst.dk/bygningsreglementet.dk/tidligerebygreg/0/40 (accessed 14.07.2011)

[23] G.A. Mertz, G.S. Raffio, K. Kissock, Cost optimization of net-zero energy house, Energy Sustainability, California, USA, 2007

[24]CEN, EN 15603:2008 'Energy performance of buildings - Overall energy use and definition of energy rating', 2008

[25]Danish Building Regulations 2010, update from August 2011 http://www.ebst.dk/bygningsreglementet.dk/br10_02/0/42 (accessed 01.11.2011)

[26] P. Hernandez, P. Kenny, From net energy to zero energy buildings: Defining life cycle zero energy buildings (LC-ZEB), Energy and Buildings 42 (6) (2010) 815-821

[27] S. Rosta, R. Hurt, R. Boehm, M.J. Hale, Performance of a zero-energy house, Journal of Solar Energy Engineering, Transactions of the ASME 130 (2) (2008) 0210061-0210064

[28] T.V. Esbensen, V. Korsgaard, Dimensioning of the solar heating system in the zero energy house in Denmark, Solar Energy 19 (2) (1977) 195-199

[29] R.W. Besant, R.S. Dumont, G. Schoenau, The Saskatchewan conservation house: Some preliminary performance results, Energy and Buildings 2 (2) (1979) 163-174

[30] T. Saitoh, H. Matsuhashi, T. Ono, An energy-independent house combining solar thermal and sky radiation energies, Solar Energy 35 (6 ) (1985) 541-547

[31] A.J. Marszal, J.S. Bourrelle, E. Musall, P. Heiselberg, A. Gustavsen, K. Voss, Net Zero Energy Buildings - Calculation Methodologies versus National Building Codes, In Proceedings of EuroSun 2010: International Conference on Solar Heating, Cooling and Buildings, Graz, Austria, 2010

[32] T. S. Larsen, Vurdering af indeklimaet i hidtidigt lavenergibyggeri - med henblik på forbedringer i fremtidens lavenergibyggeri, Technical Report No. 100, Aalborg University, Januar 2011

[33] K.N. Petersen, K. Gram-Hanssen, husholdningers energi- og vandforbrug. Afhængighed af socio- $\varnothing$ konomiske baggrundsvariable, SBi 2005:09, Danish Building Research Institute, Aalborg University, 2005

[34] M. K. Dixit, J. L. Fernández-Solís, S. Lavy, C.H. Culp, Identification of parameters for embodied energy measurement: A literature review, Energy and Buildings 42 (8) (2010) $1238-1247$

[35] M.T Iqbal, A feasibility study of a zero energy home in Newfoundland, Renewable Energy 29 (2) (2004) 277-289.

[36] W. Gilijamse, Zero-energy houses in the Netherlands, Building Simulation '95, Madison, Wisconsin, USA, 1995

[37] K. Voss, E. Musall, Net Zero Energy Buildings, Detail Green Books, Detail, Munich, 2011

[38]B. Vale, R. Vale, The New Autonomous House: Design and Planning for Sustainability, Thames \& Hudson Ltd, 2002. 
[39] W. Stahl, K. Voss, A. Goetzberger, The self-sufficient solar house Freiburg, Solar Energy 52 (1) (1994) 111-125

[40]K. Voss, A. Goetzberger, G. Bopp, A. Häberle, A. Heinzel, H. Lehmberg, The selfsufficient solar house in Freiburg - Results of 3 years of operation. Solar Energy 58 (1-3) (1996) $17-23$

[41]P. Platell, D.A. Dudzik, Zero energy houses geoexchange, solar CHP, and low energy building approach. Energy Sustainability Conference, Long Beach, California, 2007

[42]J. Kramer, A. Krothapalli, B. Greska, The off-grid zero emission building, Energy Sustainability Conference, Long Beach, California, 2007

[43]D.S. Paker, M. Thomas, T. Merrigan, On the path to Zero Energy Homes, National Renewable Energy Laboratory, DOE/GO-102001-1287, 2001

[44] K. Voss, I. Sartori, A. Napolitano, S. Geier, H. Gonzalves, M. Hall, P. Heiselberg, J. Widén, J.A. Candanedo, E. Musall, B. Karlsson P. Torcellin, Load Mathing and Grid Interaction of Net Zero Energy Buildings, In Proceedings of EuroSun 2010: International Conference on Solar Heating, Cooling and Buildings, Graz, Austria, 2010

[45] J. Widén, E. Wäckelgård, P.D. Lund, Options for improving the load matching capability of distributed photovoltaics: Methodology and application to high-latitude data, Solar Energy 83 (11) (2009) 1953-1966

[46] R. Baetens, R. De Coninck, L. Helsen, D. Saelens, The impact of domestic load profiles on the grid interaction of building integrated photovoltaic (BIPV) systems in extremely lowenergy dwellings, In Proceedings of Renewable Energy Research Conference, Trondheim, Norway, 2010

[47] B. Verbruggen, R. De Coninck, R. Baetens, D. Saelens, L. Helsen, J. Driesen, Grid Impact Indicators for Active Building Simulation, In Proceedings IEEE PES Conference on Innovative Smart Grid Technologies, Anaheim, California, US, 2011

[48] J.Widén, Value of on-site electricity generation - example calculations with different types of metering for an individual household, Uppsala University, Dep. Of Engineering \& Science, working document, 2010

[49] M. Castillo-Cagigal, E. Matallanas, D. Masa-Bote, E. Caamaño-Martín, A. Gutiérrez, F. Monasterio, J. Jiménez-Leube, Self-consumption enhancement with storage system and demand-side management: GeDELOS-PV system. In Proceedings of 5th International Renewable Energy Storage Conference, Berlin, Germany, 2010

[50] H. Lund, A. Marszal, P. Heiselberg, Zero Energy Buildings and Mismatch Compensation Factors, Energy and Buildings 43 (2011) 1646-1654

[51] Kortlægning af strategier for lavenergibyggeri i EU Lande, COWI, February 2011

[52] O.M. Jensen, K.B. Wittchen, K.E. Thomsen et al., Towards very low energy buildings, SBi 2009:03, Danish Building Research Institute, Aalborg University, 2009

[53] Sustainable Solar Housing Volume 1 - Strategies and Solutions, Ed: Robert Hastings and Maria Wall, EARTHSCAN, London, 2007

[54] Energieeinsparverordnung EnEV 2009 http://www.enevonline.org/enev_2009_volltext/index.htm (in German)

[55] Energy use in buildings, SBI-Instructions 213, 2005 (in Danish)

[56] M. Ryghaug, K.H. Sørensen How energy efficiency fails in the building industry. Energy Policy 37 (2009) 984-991 
[57] Principles for nearly zero energy buildings. Paving the way for effective implementation of policy requirements, Building Performance Institute Europe (BPIE), November, 2011

[58] M. Jakob, Marginal costs and co-benefits of energy efficiency investments. The case of the Swiss residential sector Energy Policy 34 (2006) 172-187

[59] S.K. Fuller, S.R. Petersen, Life-Cycle Costing manual for the Federal Energy Management Program., 1995th ed. Washington DC: U.S. Department Energy; 1996, p.1.1-3.11

[60] K.B. Wittchen, K. Johnsen, K.G. Sørensen, J. Rose, BSim User's Guide. Danish Building Research Institute, Aalborg University, 2011

[61] R.L. Jensen, J. Nørgaard, O. Daniels, R.O. Justesen R, Person- og forbrugsprofiler Bygningsintegreret energiforsyning, Technical Report No. 69, Aalborg University, 2011

[62] Technology Data for Energy Plants, Danish Energy Agency and Energinet.dk, June 2010 


\section{Publications}

I. A.J. Marszal, P. Heiselberg, J.S. Bourrelle, E. Musall, K. Voss, I. Sartori, A. Napolitano, Zero Energy Building - A Review of definitions and calculation methodologies, Energy and Buildings 43 (2011) 971-979

II. A.J. Marszal, P. Heiselberg, Life Cycle Cost analysis of a multi-storey residential Net Zero Energy Building in Denmark, Energy 36 (2011) 5600-5609

III. A.J. Marszal, P. Heiselberg, R.L. Jensen, J. Nørgaard, On-site or off-site renewable energy supply options? Life cycle cost analysis of a Net Zero Energy Building in Denmark, Renewable Energy (accepted for publication 01.12.2012)

IV. A.J. Marszal, J.S. Bourrelle, J. Nieminen, B. Berggren, A.Gustavsen, P. Heiselberg, M. Wall

"North European Understanding of Zero Energy/Emission Buildings" In Proceedings of Renewable Energy Research Conference, Trondheim, Norway, 2010, pp. 167-178

V. A.J. Marszal, J.S. Bourrelle, E. Musall, P. Heiselberg, A. Gustavsen, K. Voss, Net Zero Energy Buildings - Calculation Methodologies versus National Building Codes, In Proceedings of EuroSun 2010: International Conference on Solar Heating, Cooling and Buildings, Graz, Austria, 2010 